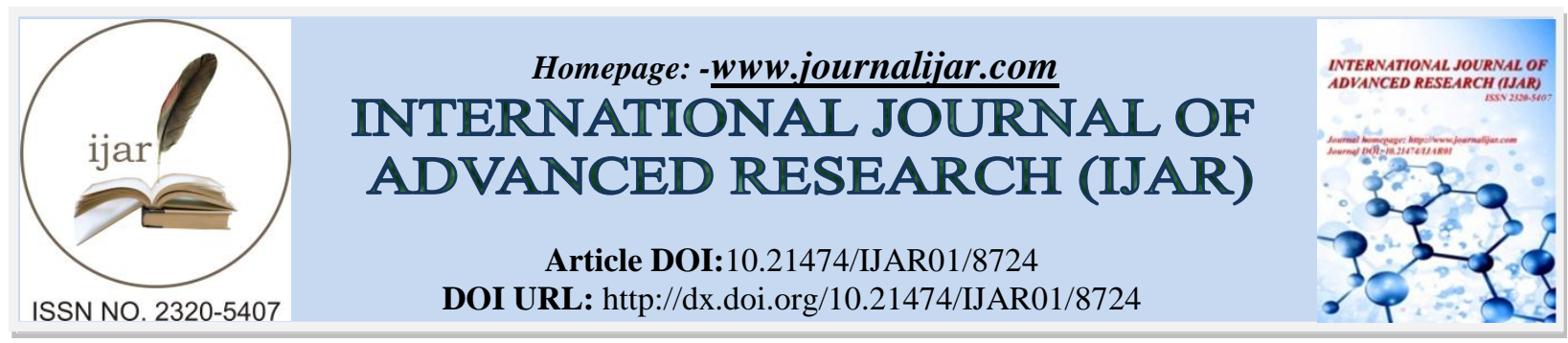

RESEARCH ARTICLE

\title{
GEO-BIO CHEMISTRY OF WETLANDS IN LATERITE MINES, THE CHILIKA CATCHMENT, ODISHA:GIS STUDY AND XRFSPECTROSCOPY APPRAISAL.
}

Aishsurwaya Das ${ }^{1}$, Siba Prasad Mishra ${ }^{2}$, G.D.Pattanayak ${ }^{3}$ and Kumar Chandra Sethi ${ }^{4}$.

1. Research scholar, Dept of Life Science, Centurion University of Technology of Management, BBSR, Odisha.

2. Department of Civil Engineering, CUTM, BBSR.

3. Principal, Department of Pharmacy, Centurion University of Technology of Management, Odisha.

4. Department of Civil Engineering, Centurion University of Technology of Management, Odisha.

\section{Manuscript Info}

(.........................

Manuscript History

Received: 17 January 2019

Final Accepted: 19 February 2019

Published: March 2019

Key words:-

Laterite, XRF spectrometer, Soil map,

GIS, Water quality, Odisha.

\section{Abstract}

Laterites in Odisha cover $\approx 7000 \mathrm{Km}^{2}(4.5 \%)$ surface area of the state. As hard and vesicular, laterite blocks are common local construction materials. The latsol areas are quarried open air and water bodies are formed in those ditches. Fresh water bodies within the mines cover $\approx 60-70 \%$ of the quarry area during rainy season. Those water bodies have poor in flora and fauna and specially aqua habitats. The water quality parameters are of concern in those ferruginous laterite zone. The aquatic life depends on the physical, chemical and biological parameters of water but adequate research has not been done to assess the cause of paucity of aqua habitats in these semi dead zones. Evaluation of toxic chemicals, physical parameters and finally tried to find causes that has made these wetlands as semi dead zones and very poor growth of aqua habitats and consequently the avifauna and floral diversity. These wetlands cannot be used even for economic fish or prawn farming, for recreation and domestic uses except less hygienic bathing. The present search is to identify the causes of unsustainable environments for aquatic life. Assessment of laterite area in the Chilika catchment has been evaluated using supervised classification of multispectral Landsat- 8 images. The method found the area to be $744.456 \mathrm{Km}^{2}$ consideringpHas parameter. The toxic elements, metals, metalloids and REE's were found by using XRF Spectrometer, and BOD/ COD. The concentration of physical, toxic alkali/alkaline earth elements, harmful REE's and radionuclides and biological parameters are sorted out causing the meager flora and fauna. The stagnated water bodies in laterite mines are with overdoses of $\mathrm{DO}$, and $\mathrm{Fe}$ and $\mathrm{Al}$ contamination.

Copy Right, IJAR, 2019,. All rights reserved.

\section{Introduction:-}

Laterite (Latosol), named by Buchanan F., $1807^{[1]}$, who diagnosed the latosol, a crystalline rock of WGB Hills, which is rich in oxides of iron, aluminum, and nickel but lack of $\mathrm{N}, \mathrm{P}, \mathrm{K}$, primary silicates and kaolinite. The existence of such rocks is of equatorial, tropics and sub-tropics of the earth and formed by leaching due to weathering action of torrential rain of tropics and high temperature during summer.Mostly laterite is of tarnishing 
iron colour, due to high $\mathrm{Fe}_{2} \mathrm{O}_{3}$ content and less clay.The laterite rocks is porous in mines are capping hill tops and adjacent plateau. The ferruginous rock covered by morrum (Soil form) extends underneath up to 12 to $15 \mathrm{~m}$ by prolonged weathering covered by carboneous frustum and vegetation as overburden. The Laterites areas lies on the exposed surface of land and undergoes continuous deformation due to environmental changes.

Laterites in Odisha cover $7000 \mathrm{Km}^{2}$ of surface area which constitutes $4.5 \%$ of the total area of the state. As laterite rocks are good construction materials in those areas most of the areas are quarried and ditches are formed in quarry areas. The Water bodies are formed within these mines covering $20-30 \%$ of the quarry area and it is observed that the wet bodies are deprived of flora, fauna and especially aqua habitats. Economically the water bodies have least

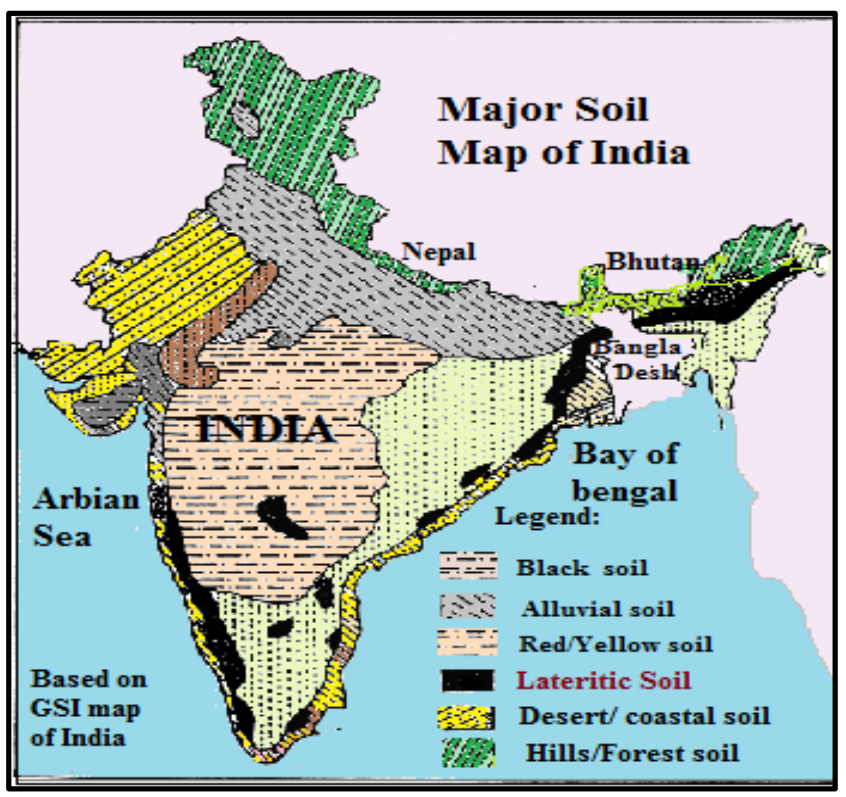

uses for the human uses and water quality, physic parameters are of concern in the ferruginous laterite zone.

The natural building material are preferred in world as well graded admixture of both cohesive (clay and silt) and the cohesion less (gravel, chips and sand) and strong due to iron richness. Crops like cotton, rice, wheat, pulses, tea, coffee, rubber, coconut and cashews are cultivated in humus laterite soils though it is less yielding.Latosol stretches are found in Guatemala, Central Europe, Colombia, India, Burma, Precambrian shields of Brazil and Australia. The soil is acidic, low water retentivety and has less nitrogen and lime. They occur in parts of Tamil Nadu, Karnataka, Andhra Pradesh, Orissa and Jharkhand.

\section{Laterite soils in India:-}

The Laterite alternately called ferric rete is a left over ferruginous rock seen in tropics and subtropics has the mineralogical and chemical configuration of latosol/laterite governed by on their base rock manly bauxite. Laterite soil and red soils are not identical. The barren lands with red soils are formed by leaching process in tropical heavy rainfall areas. These soils are crystalline and red in colour due to little clay and more concentrations of iron, aluminum, manganese and nickel which is found in the hills of Deccan plateau, Karnataka, Kerala, Odisha, Assam and Meghalaya in India (Fig 1). But the less fertile, poorly crystalline laterite soils (morrum) are formed by weathering action of igneous and metamorphic rocks but dipper the extent richer the soil and more the fertility. The red colour of the soil is due to less clay content and higher gravel of red sand-stones https://brainly .in/ question / $\underline{1182741 .}$.

\section{Review of Literature:-}

Nomenclature, classification, morphological and analytical characteristics, global distribution, processes of horizon development, environmental conditions of laterites are analyzed by Alexander et. al., (1962) ${ }^{[2]}$, Maignien R., 1966 
${ }^{[3]}$, Thomas M. F. (1974) ${ }^{[4]}$,.Niyogi D. et al., $1973^{[5]}$, Raychaudhuri S. P., $(1980)^{[6]}$, Wadia $(1999)^{[7]}$ and Ollier et., al., $(2008)^{[8]}$ and Mishra S.P. et al $(2018)^{[9]}$ have investigated various profiles of lateritic deposits in Peninsular India and tried to solve the problems of origin of Indian laterites. The general belief is that the high-level or primary laterites were formed due to in situ chemical weathering of basalt plateau in the monsoon wet - dry climate and lowlevel or secondary laterites are formed by denudation and transport of primary laterites and cementation of accumulated detritus Transactions. Ollier and Sheth $(2008)^{[8]}$ have mentioned the inversion of relief hypothesis in place of the ferric rete plain hypothesis to explain the origin of high Deccan duricrusts of India.

The laterites of West Bengal having similarity with laterites of Odisha are investigated by Hunday et al., 1967 ${ }^{[10]}$, Mallick S., et al., $1972^{[11]}$, Goswami A. B., $1981^{[12]}$, Vaidyanadhan R. et. al., $1993^{[13]}$, Chatterjee N., 2008 ${ }^{[14]}$, Ghosh S. et. al., $2015^{[15]}$. They have provided significant geological and geomorphological explanations of lateritic landforms which carry distinct palaeogeographic individuality of this northwestern marginal part of the Bengal Basin. The formation of stratum of primary laterites are genetically linked with the parent rock i.e. Rajmahal basalt and Gondawana sand stones in W.B. and secondary ferruginous laterites are of Quaternary-Tectono-climatic evolutions due to fluvial fan deltaic deposition Ghosh S. et. al.,2015 ${ }^{[15]}$.

Laterites are formed on weathering in tropically heavy rainfall areas. These weathering processes involve leaching of silicon dioxides, formation of sesquioxides in colloidal form Bandyopadhyay S., $1988^{[16]}$. Precipitation and runoff of the sesquioxides from the soil is the primary cause of laterite formation and causing porosity. Subsequently there is crystallization by evaporation of water. Dehydration transforms the rock to porous hard layers of laterite. The feldspars, quartz, and ferromagnesian minerals are transformed to a porous clayey system containing kaolinite, sesquioxides, and some residual quartz. The primary feldspars is converted to kaolinite and then to gibbsite. The minerals of ferromagnesian, are converted to diffused goethite in crystalline form and finally to the iron ore, hematite containing iron and/or aluminum oxide and available in the earth's crust Tuncer E. R., $1976^{[17]}$. Geospatial climatic variability after tectonic stability or together with slow geomorphological evolution over periods of 1015years are significant to the development and destruction of laterite profiles Mike W., 2009 ${ }^{[18]}$.

The lime and silica present in soil are precipitated out with the runoff from latosol zones and wetted hard rocks areas. Porous laterite stones are soft when in mines and become formed rich with iron and with patches of bauxites Das $\mathrm{K}$ et al $1995^{[19]}$. The humus content is removed by bacteria's which can thrive in temperate zone. Consequently the latosols are poor in nitrogen, phosphate, calcium and organic matter but rich with oxides of iron, Aluminum and potash. Laterite when freshly quarried is soft and can be cut to bricks but become hard/ compact when exposed to the air. In reverse loose fragmented morrum and laterite gravels recemented geospatially to form compact laterite rocks Mishra S P., et al., 2017 ${ }^{[20]}$.

Ray Choudhury S P. $1980^{[6]}$ reported that laterite (latosol given by Kellog 1949) a type of soil rich in sesquioxides clay that transforms to hard pans due to alternate wetting and drying due to heavy rain in tropics and subtropics and finally to a porous medium hard rock which can be cut by pick axes and crowbars in laterite mines.

Laterite, the highly weathered solid contain2ndry oxides of $\mathrm{Fe}$, $\mathrm{Al}$ or both but devoid of primary silicates and kaolinite Tuncer E. R, $1976^{[17]}$, Chattopadhyay et al, $2003^{[21]}$, Banerjee et al $2009^{[22]}$, reported that the aqua habitats growth in stagnated water (ponds) in latosol areas have poor nutrients and particularly phosphorus $(\mathrm{P})$ concentration (conc.) and can be improvised by application of monthly with 20,15 , and $3 \mathrm{~kg} / \mathrm{ha}-1$ application -1 of $\mathrm{N}, \mathrm{P}$, and $\mathrm{K}$, fertilizer and lime to augment primary food production of aqua fauna. Kanwar et al, $1971^{[23]}$ had studied soils of different states of India (except Odisha) and reported that iron and aluminum is at higher conc. in laterite soils of Kerala and TN whereas, Ca-P was found in traces. The laterite extent is initiated over the unconsolidated secondary deposits during Pleistocene epoch (1.8Myears BP) when herbs dominated over the frustum of earth and reworked latter by sub aerial weathering Oldham R.D., 1939 ${ }^{[24]}$; Niyogi D., $1975^{[25]}$, Bandyopadhyay S., 1987 $7^{[26]}$, Das et al., $1995^{[27]}, 1996^{[28]}$; Dey et al. 2009 $9^{[29]}$, Ghosh et al 2015 $5^{[15]}$

Soluble Alkali, alkaline earth metals and Arsenic, in forms of oxide, chloride and fluoride form, heavy metals like $\mathrm{Fe} 2+, \mathrm{Cu} 2+, \mathrm{Zn} 2+, \mathrm{Mn} 2+, \mathrm{Ni2}+, \mathrm{Pb} 2+$ are toxic and some undesirable plants which accumulate heavy metals also noxious to the users of the water and flora and faunal kingdom. Their presence may contaminate the food web of the both primary and secondary, nutrients of both soil and water. Adnan Amin 2010 ${ }^{[30]}$., Mishra S. P. et al., 2017 $7^{[31]}$, HodaAbd El-Azim, et. al., 2018 ${ }^{[32]}$ has reported that the health risk direct to the fishes and then the humans are 
affected by heavy metals(Methyl Mercury) which is accumulated in their internal organ. Vegetation is a major another important cause of creation of laterites. Sherman et al. $1953^{[33]}$ reported that the colloidal hydrated oxides which enter the runoff by dehydration from the frustum and the base stones become vesicular.

As vegetation regulates dehydration and erosion, is the prime factor for ferruginous laterite formation. Laterite (alternatively named Ferrocrete) are the burnt clay brick coloured vesicular ferruginous stones cover the frustum of hills found in tropic and subtropics comprising of oxides of $\mathrm{Fe}$ oral with oxides of $\mathrm{Si}$ and other hydroxides/ oxyhydroxides and kaolinite of general form, $\mathrm{SiO}_{2}: \mathrm{R}_{2} \mathrm{O}_{3}$, (where, $\mathrm{R}_{2} \mathrm{O}_{3}=\mathrm{Al}_{2} \mathrm{O}_{3}+\mathrm{Fe}_{2} \mathrm{O}_{3}+\mathrm{TiO}_{2}$ ) in study area which hardens when exposed to alternate drying and wetting Alexander and Cady 1962 ${ }^{[2]}$; Maignien R., $1966^{[3]}$; McFarlane et al., 1976 ${ }^{[34]}$; Tardy Y., 1992 ${ }^{[35] .}$ Slaninova A., et al., $2014^{[36]}$ has reported that fishes die due to Fe and Al contamination in Ponds. The Laterite is compartmentalized basing upon its basement, nature, colour, conc of iron/bauxite, abundance, the weathered profile, landscape and vegetation Kale H. S. $2016^{[37]}$.

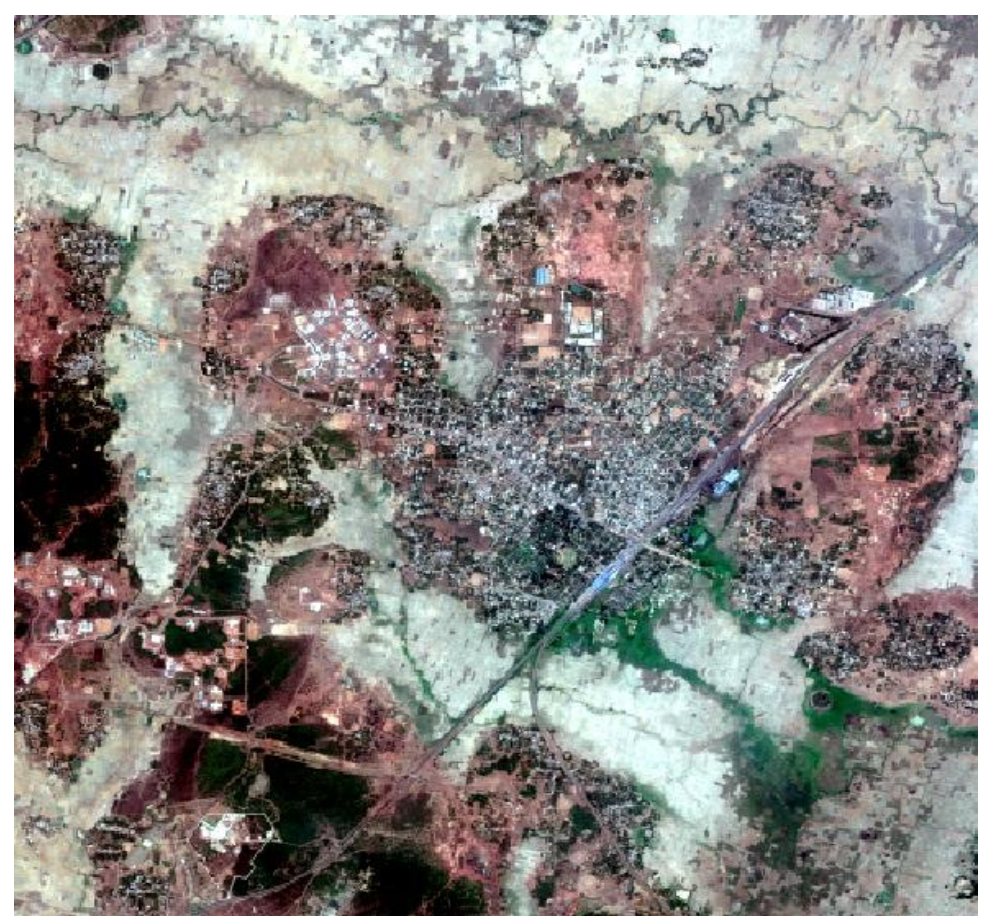

Fig 2:-Zoomed view to identify lateritearea at Jatni, Khordha

\section{Research overview:-}

Laterites of Odisha (covering $\approx 7000-8000 \mathrm{Km}^{2}$ ) has its unique quality, long term glitches, and placed within the arena of geo-biography, morphology, hydrology and limnology research gaps. Ministry of Mines, Indian Bureau of Mines considered in its Minerals Yearbook 2016 about reserve of 1227,000 MT of laterite in Odisha.The laterite extensions occur below soil/ lateritic soil, the depth ranges from $0.2 \mathrm{~m}$ to $15 \mathrm{~m}$ in old undivided Puri district. Due to enrichment of iron, at places, this laterite is very hard at specific horizons, which enhances its cost as in Puri (Delang block only), Khurdha and Nayagarh districts of Odisha.

The ubiquitous exposure of laterites in western catchment of Chilika Lagoon and south Mahanadi Delta along east coast of Odisha is not favourable for growth of flora and fauna in ponds formed within laterite mines may be due to lethal chemicals. The sustenance of aquatic life depends on specific the physical, chemical and biological parameters of the water bodies and depends upon primary nutrients and the primary food chain. Evaluation of physical, chemical, toxic metals and other parameters cause these wetlands as semi dead zones due to shortage of adequate food web chain and finally the avifauna and floral diversity. The huge wet lands could not be used economically as irrigation, recreation, domestic and aqua culture potential. The present investigation is in search of that sustainable enviornments of aquatic life through finding out presence of the toxic alkali/alkaline earth elements, 
harmful REE's and Radionuclides. A detailed research has been done to assess the cause of failure of aqua farming in these dead zones.

\section{Aim of study:-}

As observed that the laterite exposed mines areas are barren,less vegetation and less aqua habitats in water bodies formed in the laterite mines of Odisha. It is proposed to probe the physical, chemical and bacteriological deficiencies for poor/zero growth of fish and other habitats in these water bodies andevaluation of the chemicals that cause toxicity to aquatic life. The aims of the studies are:

1. The zoomed view of land sat image- 2018 of the study area to identify the laterite areas Fig-2.

2. The lithological map of laterite areas is to be prepared from satellite imagery by the method of supervised classification. The signatures of the $\mathrm{pH}$ values are prepared by taking the $\mathrm{pH}$ values of the water in laterite mines.

3. To assess the area of exposure of laterites and the water spread area in the laterite mines by using GIS.

4. Definition, identification, mode of formation and classification lateritic extensions in Odisha.

5. Determination of the approximate age of formations of laterites, the paleo-climatic indicators,

6. Identification of the extensions of water bodies in the lateritic mines and seasonal water availability.

7. Evaluating the physico-chemical and biological limitations causing aquatic life toxic and short-lived.

8. Collection, Identification of sources and potential problems created due to these sources.

9. Identify appropriate methods collection, sampling and laboratory procedures.

10. Finding the physical, chemical and biological character of the natural ponds in laterite zone like $\mathrm{pH}, \mathrm{EC}$, Turbidity, SPM, DO, BOD, COD, and coliforms present if any.

11. The Spectrophotometric and Flame-photometric studies to find the presence of alkali and alkaline earth metals present in those liquids. Specially concentrations of nitrogen, phosphorous $(\mathrm{P})$, potassium $(\mathrm{K})$, calcium $(\mathrm{Ca})$ and the primary nutrients of the food chain.

12. XRF spectroscopic studies have been conducted to identify harmful heavy metals like Lead (Pub), Cobalt (Co), Cadmium (Cd), Zinc ( $\mathrm{Zn})$, Copper (Cu), Manganese (Mn), Chromium (Cr), Arsenic (As), Nickel (Ni), Iron $(\mathrm{Fe})$, Fluoride $(\mathrm{F})$, and Mercury $(\mathrm{Hg})$ if any and their conc.

13. Investigation of the adequacy of the chemical ingredients for aqua habitats for their growth in ponds formed due to laterite mining.

14. Study of growth of aqua-habitats in the ponds in laterite mines at the extreme season (Summer)

\section{The study area:-}

The resilience part of the duricrust with lateritic covering profiles has played a pivotal role in landscape formation of the northerly fag end of EGB Hills range, the study area in Odisha. Laterite Sub-regions in the undivided Puri district are blocks such as Delang, Pipili, Bhubaneswar, Ranapur, Nayagarh, Banapur, Bolagarh, Begunia, Khurda, Jatni, and Tangi. Khurda district has $2813 \mathrm{~km} 2$ in area is bounded between $\left(19^{\circ} 40^{\prime} \mathrm{N}\right.$ and $20^{\circ} 27^{\prime} \mathrm{N}$ lat.and $84^{\circ} 56^{\prime}$ $\mathrm{E}$ and $86^{\circ} 05^{\prime} \mathrm{E}$ long.) is having population 2251673 persons as per 2011 census. The mines are over exploited from Jatni, Banapur, Begunia, Bolagarh, Khurda and Tangi to get laterite slabs for construction of buildings. The laterite clusters over khondalites and charnockites were due to drifting of Indian Plate, neo-tectonic uplifts, relateritisation of ferruginous shelf deposits and climate anomalies Roychoudhury et al, $1980^{[6]}$. Laterite caps over bedrocks arise as overburden due to alternation of the Gondwana sand stones and underlain by Khondalite and Charnokites(Fig -2). The spread is deep up to $15 \mathrm{~m}$ at the flat part of the copings of the hills and gradually reduces in depth in slopes and gradients in the study area.

The USGS Landsat $0.5 \mathrm{~m}$ resolution data was taken for analysis. The red colour laterite bedded area is directly visible from high resolution image data (Fig 2). The red colour is considered as the laterite covers which are unveiled by mining of laterite slabs. The depressed area within the mines receives the runoff from its catchment area and ponds are formed within the ditches made by mining activities. The pools formed are up to brim during rainy season but dries up in summer leaving behind stagnated water body for use of the nearby villages for cleaning bovines and bathing purposes. Five of such ponds ad two more sampling stations has been identified to collect pond/sea water one along the alluvial region and the other within the study area Fig $\mathbf{3}$. 
The laterite mines are infertile lands with no or little vegetative growth, with less agricultural activities and economically utilities. As the terrain is sloppy, and lies in the heavy rainfall areas of $1500 \mathrm{~mm} /$ year, huge amount of runoff occurs and decants through rill/gully/nallas to nearby historical river the Daya Mishra et al., $2017^{[31]}$.

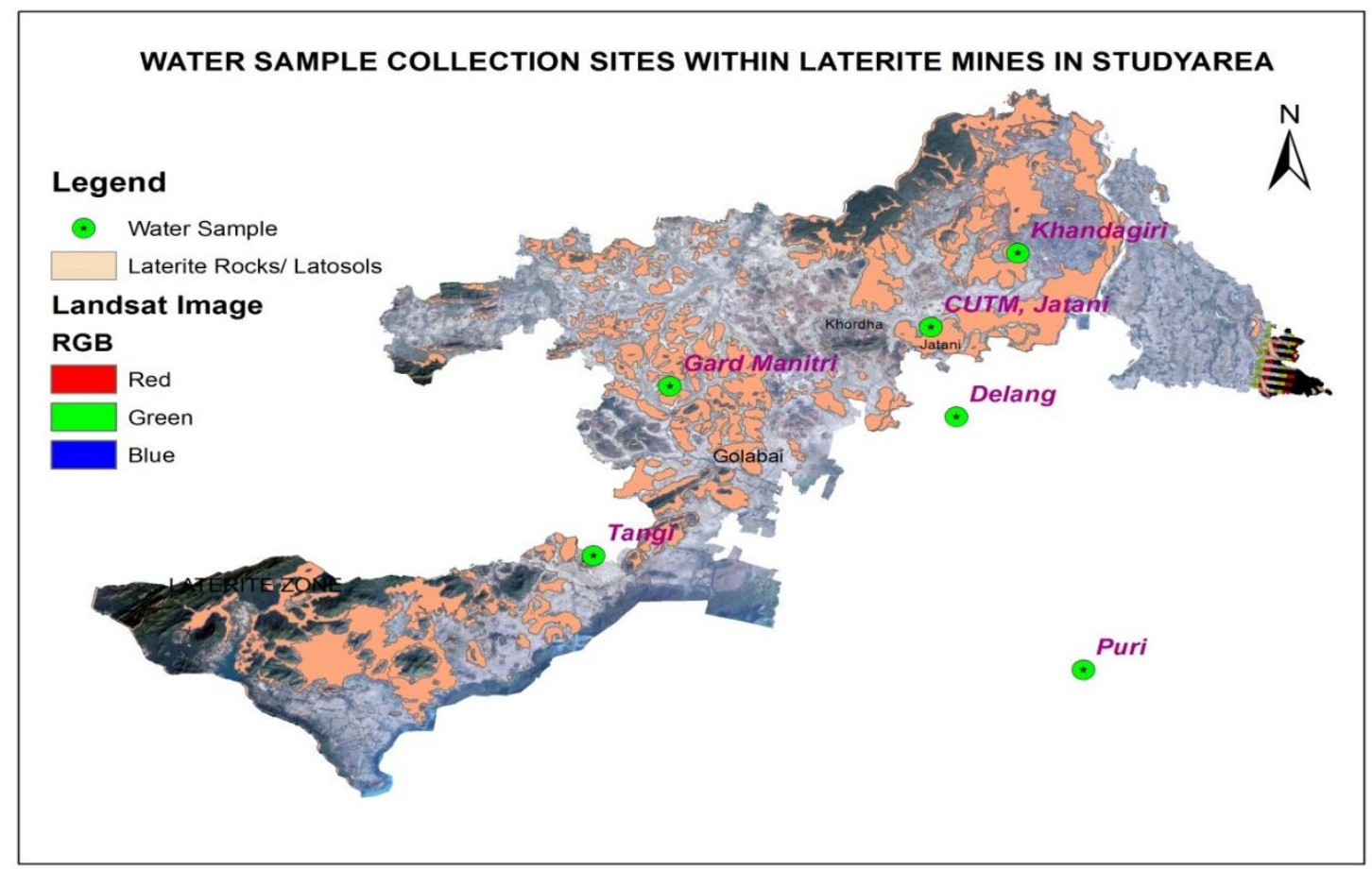

Fig3:-The sample collection sites within the study area

\section{Lateritisation in India:-}

Laterite, the weathered iron/aluminm stone product derived from various parent rocks through the process of lateritisation i.e. the product of alternate weathering of exposed parent rock from tertiary period in tropical and subtropical region due to heat in summer and leached due to heavy rain during monsoon period. The soluble elements flow away as runoff leaving behind insoluble salts of iron, alluminium, Nickel etc. Gradually layers of such soil piled up to form porous rocks with cleavage and the layers are separated by layers of other soils. The formation occure as sheets (10to 15years deposit) as it is oriented by climate, Aeolian forces, vegetation and topology of the area.

The inert Kaolinite, the major component of soil, undergoes weathering action and decreses in volume.Thesesquioxides of iron/aluminum increase in amount. Kaolinite acts as a binding agent where assesquioxides serve as a cementious agent. So long as, there is available of sesquioxides in the soil, aggregation proceeds in the direction of forming larger and larger aggregates of latosol. As weathering proceeds further, sesquioxide content keeps on increasing, leading to the formation of larger lateritic soil aggregates. Finally in due course of weathering, lateritic soils possess a granular quality and formations of laterite beds occur.

\section{The Soil map of the study area:-}

The Land Sat imagery of 2018 of Khordha districts down loaded from USGS site. The water quality studies from 2009 to 2014 from different literature and sources are collected such as govt, semi government, and private and literature sources. The physicochemical parameter such as $\mathrm{pH}$ is plotted on the imagery. Iso- $\mathrm{pH}$ lines are drawn indicating $\mathrm{pH}$-values from 4.0 to 6.82 . Since laterite soils bear $\mathrm{pH}$ value ranging from 4.0 to 7.0 the areas with brick orange colouration were considered as exposed laterite area. The ground trothing of the areas of exposed laterite were verified and found to be true.

Laterite soils occupy $7000 \mathrm{Km}^{2}$ of districts Puri, Khordha, Cuttack, nayagarh, keonjhar, Dhenkanal, Mayurbhang and Sambalpur in Odisha (https://odisha.pscnotes.com/geography-orrisa/soils-of-odisha). The study areas 
constituteundulating hilly terrain of Gondwana, Alluvium,Aanthroposites and Khondolites. They are primarily overlain by laterite caping or latosol or alfisols in hilly terrain. The underlain rocks are primarily Gondwana or precamberian hard rocks which are bases of EGB hills range. The geological sub-units of the terrain are pediments, pediplains, intermontane valley, residual or structured hills and anthroposite deposits.
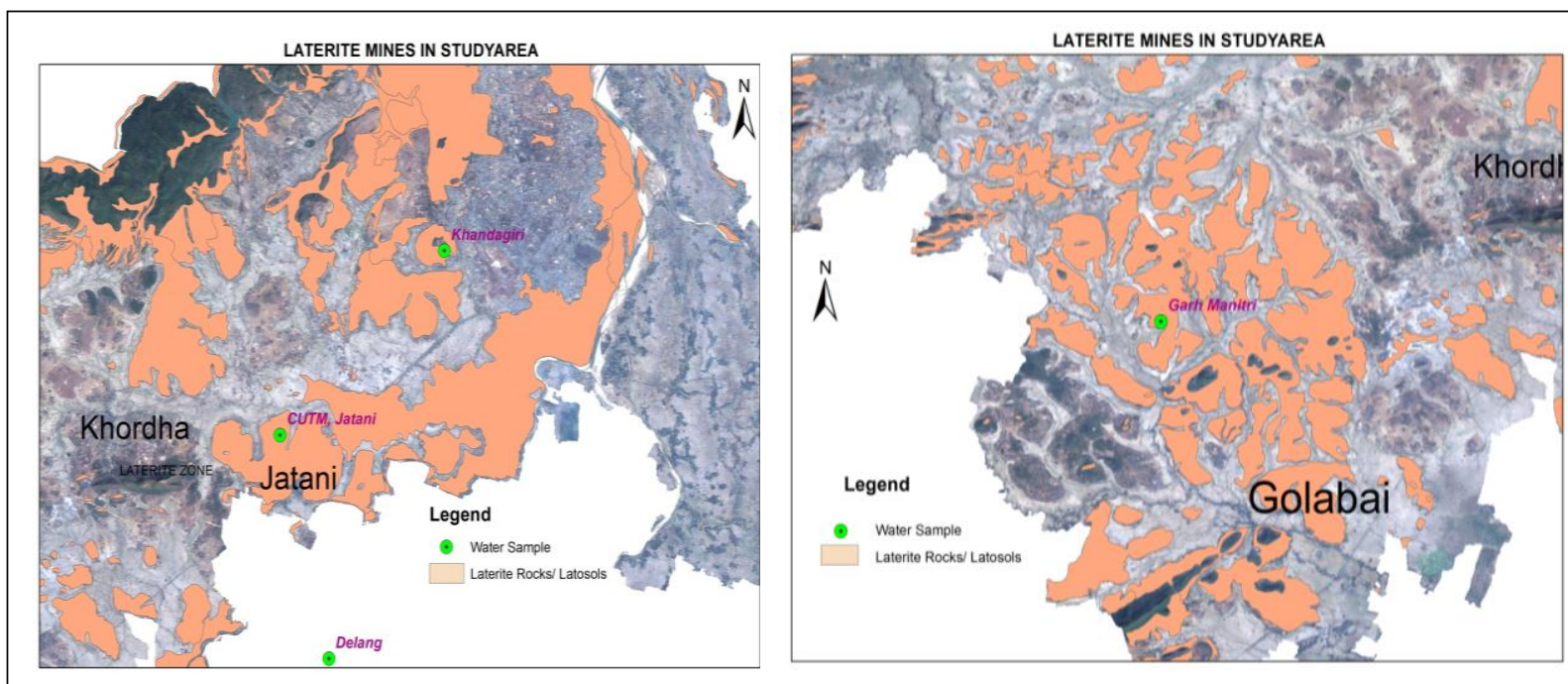

Fig 4(a):The Zoomed view of laterite mines at Jatni Fig 4(b): The dense laterite area at Golabai.

The USGS Landsat imagery of 2018 was taken for the study area. Pixels are chosen on the satellite imagery on personal visit to the where laterite areas were found. Signature of file was created. Taking samples of water from the laterites the $\mathrm{pH}$ values were collected/observed. The image was classified taking the sample of $\mathrm{pH}$ values lying between 4 to7. Then the area was marked by using supvising classification of image using ERDAS imagine software for the dense laterite areas Jatni and Golabai in study area Fig 4 (a) and Fig 4 (b) . Laterites capping found in protuberant manifestations are in Bolagarh, Jatni, Delang, Khurda, and Bhubaneswar and in Tangi areas. The average vertical extension over consolidated and semi consolidated formation and is around $20 \mathrm{~m}$. Assessment of laterite area in the Chilika catchment has been evaluated using Landsat-VIII image downloaded from USGS site by supervised classification of multispectral Landsat images method and was found to be $744.456 \mathrm{Km} 2$ considering $\mathrm{pH}$ as parameter.

\section{Hydrology of the area:-}

Hydrologic ally the study area lies in subtropics with unique hydrological features. These laterites in study areas are lying between 05 to $50 \mathrm{Km}$ from coastal land forms having annual rainfall $\approx 1500 \mathrm{~mm} /$ year with $75-80 \%$ rainfall during SW monsoon period (JJASO months). The average humidity is $\approx 79 \%$. Since the laterite rocks are porous and in hilly terrain, the runoff is seriously affected by infiltration and less vegetation resulting less evapotranspiration. Some small to large drainage channels are flowing in the areas with av. velocity of flow $0.1-0.2 \mathrm{~m} / \mathrm{sec}$ in summer to 1.5 to $2.2 \mathrm{~m} / \mathrm{sec}$ in floods. The wet lands formed within the mines are filled up in rainy days and the depth of water depletes up to $1.0 \mathrm{~m}$ and some areas become dry even during summer. The ground water of the areasare largely affected by the vesicular properties of the bed of laterites. The variations in GWT are depleting in a steady pattern and the residence period is 2-6months. During summer days the ground water depletes faster and variation becomes 4-10m (GOO sources).

\section{The water bodies within laterite zone:-}

The water bodies in the study areas are visited and as per ground truth results by sampling method it was found the areas identified are correct. The water bodies are abundant during rainy season and decrease to $\approx 20-30 \%$ in extreme summer. The water bodies developed within the laterite zone of Jatni area during monsoon is in fig 5 


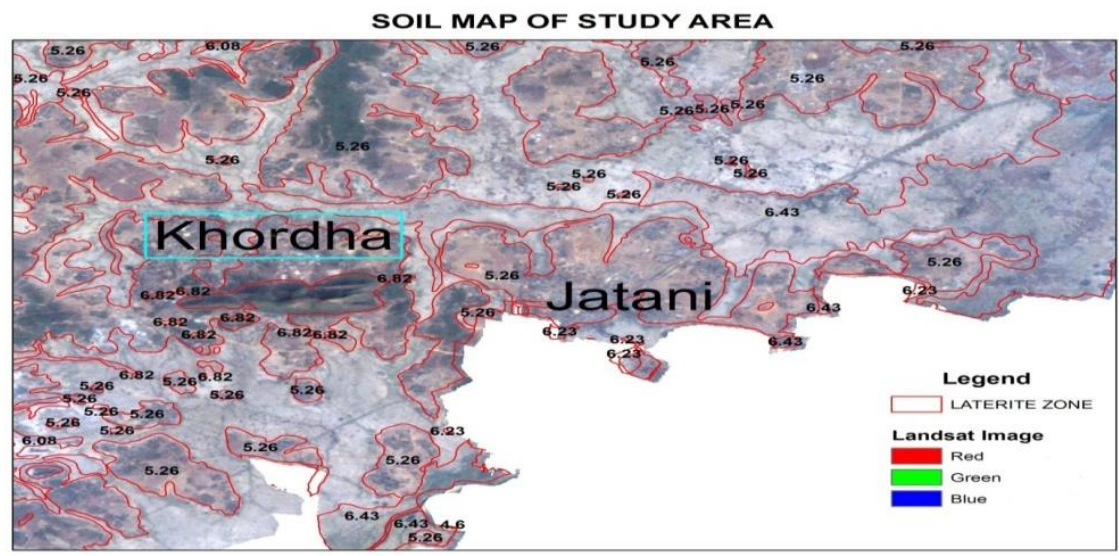

Fig 5:-TheZoomed view of laterite mines at Khordha and Jatni area

\section{Classification of laterites of Odisha:-}

Anthony Young, 1976[36], Raychaudhury S.P. 1980[5], Kale H.S. 2016[35] has classified the laterite distribution of laterites of Odisha as Massive laterite (incessant hard fabric as cellular and vesicular of rounded cavities. Laterite, Nodular laterite: rounded concretions, subdivided into cemented nodular laterite of iron concretions, Recemented laterite: fragmented of massive ferruginous laterite, Ferruginized rock: visible rock structure with extensive isomorph us auxiliary iron. Soft laterite: Mottled rich-clay hardened on exposure to air and recurrent wetting and dehydrating. Laterites in Odisha can be divisible into two types: Low level laterite: (1to $12 \mathrm{mt}$ ) and then hematite.

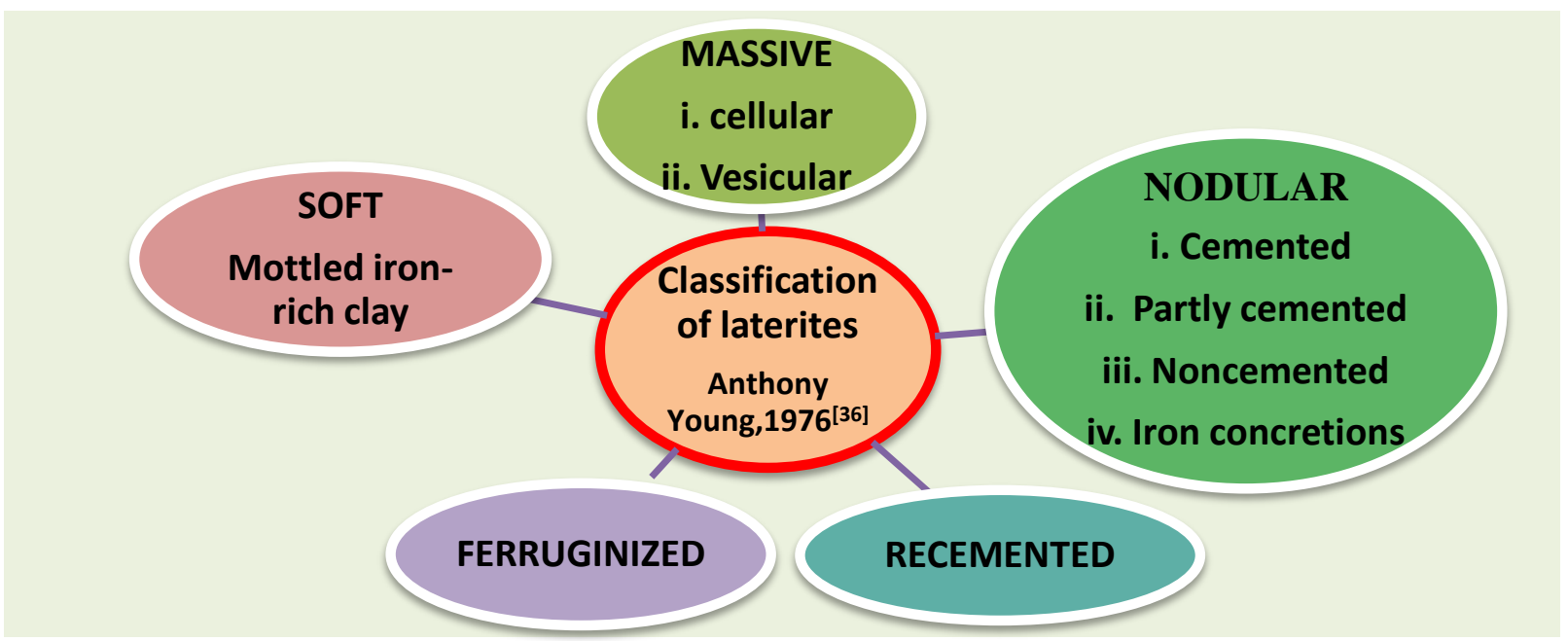

Fig 6: Classification of laterites according to Young and Ray choudhury

These vesicular laterites are exposed in plains and EGB hills are partly lateralized filled up with hard silt matrix. The study area in laterite zones of Old Puri districts has abundance in laterite cover except the coastal belt. The type of laterites in the study areas are recemented secondary formation low level vesicular laterites with major constituent as iron and silica. The classifications of various laterites are given in Fig 6.

\section{Methodology:-}

Assessment of laterite area in the Chilika catchment has been evaluated using Landsat-VIII image downloaded from USGS site by supervised classification of multispectral Landsat images method and was found to be $744.456 \mathrm{Km} 2$ except some patches of Delanga block in Puri district and some covering in Bolagarh block of adjacent Nayagarh district, considering $\mathrm{pH}$ as parameter. Water, as a dynamic medium varies in its quality in short term/ long-term and also geospatially with change in climate, sun earth geometry, geochemically, geomorphologically and also due to anthropologic pollutions. To portray any water body, hydrologic, physico-chemical and biological studies needs to 
be conducted. The biota in the latosol water is ruled by several ecological settings that determine its biodiversity. The primary production of organic matter, in the form of algae, phytoplankton and macrophytes are rare in ponds formed in latosol mines http://wgbis. ces.iisc.ernet.in/energy/monograph1/Casepage1.html,

Water Standards for flora/fauna forinland water:-

According to UNECE-1994 norms, global sustainable surface water used for outdoor bathing, drinking after treatment, propagation of fisheries and wildlife and for agriculture the values of different parameters taken by different organizations in different countries are in Table 1:

Table 1: Bio-geo-chemical parameters permissible limits for drinking, bathing, and sustenance of flora and fauna in fresh water ponds

\begin{tabular}{|c|c|c|c|c|c|c|}
\hline Source & $\begin{array}{l}\text { Drinking without } \\
\text { treatment \& } \\
\text { disinfection }\end{array}$ & $\begin{array}{l}\text { Outdoor } \\
\text { bathing } \\
\text { (organized) }\end{array}$ & $\begin{array}{l}\text { Drinking with } \\
\text { treatment \& } \\
\text { disinfection }\end{array}$ & $\begin{array}{l}\text { Wild life and } \\
\text { fisheries } \\
\text { growth }\end{array}$ & $\begin{array}{l}\text { Irrigation, } \\
\text { Industry, } \\
\text { controlled } \\
\text { waste disposal }\end{array}$ & Source \\
\hline Class & A & $\mathrm{B}$ & $\mathrm{C}$ & $\mathrm{D}$ & $\mathrm{E}$ & \\
\hline $\begin{array}{l}\text { CPCB- } \\
2008, \\
\text { India }\end{array}$ & $\begin{array}{l}\text { Coliform MNP: } \\
\text { <50/100,Turbidity } \\
\text { : 10unit, Colour: } \\
\text { 10units, TDS:500 } \\
\text { mg/l, BOD:<2 } \\
\text { mg /l, DO: } 6 \\
\text { mg/l, Toxic:Not } \\
\text { lethal ,Plate } \\
\text { count: <50/100ml, } \\
\text { Floating: Taste/ } \\
\text { odor:agreeable }\end{array}$ & $\begin{array}{l}\text { Coliform } \\
\text { MNP:<50/100, } \\
\text { Turbidity:<25u } \\
\text { nits } \\
\text { Colour }<10 \text { unit } \\
\text { BOD: } 3 \mathrm{mg} / 1 \\
\text { DO }>5 \mathrm{mg} / 1 \text {, } \\
\text { Toxicity: not } \\
\text { lethal, Floating } \\
\text { :nil,Taste/Odor } \\
\text { :agreeable }\end{array}$ & $\begin{array}{l}\text { Coliform } \\
\text { MNP:<5000/1 } \\
00 \mathrm{ml} \\
\text { Colour:<25uni } \\
\text { t, TDS }<1500 \\
\mathrm{mg} / \mathrm{l}, \\
\text { BOD: }<3 \mathrm{mg} / \mathrm{l} \text {, } \\
\text { DO: }>4 \mathrm{mg} / \mathrm{l} \text {, } \\
\text { Tox } \\
\text { incants: No } \\
\text { acute toxicity } \\
\text { to be present }\end{array}$ & $\begin{array}{l}\text { Coliform } \\
\text { MNP: } \\
<5000 / 100 \mathrm{ml} \\
\text { BOD: }<6 \mathrm{mg} / 1 \\
\text { DO: }>4 \mathrm{mg} / 1 \\
\text { Toxicants: No } \\
\text { acute toxicity } \\
\text { to be present }\end{array}$ & $\begin{array}{l}\text { TDS }<2100 \mathrm{mg} / \mathrm{l} \\
(\mathrm{Ca}+ \\
\mathrm{Mg}):<100 \mathrm{mg} / \mathrm{l} \\
\text { units, S.A.R: < } \\
10(\text { millimole } \\
\text { /liter }{ }^{0.5}, \mathrm{Chlorid} \\
\text { es: }<250 \mathrm{mg} / \mathrm{l} \\
\text { Boron: }<2 \mathrm{mg} / \mathrm{l}\end{array}$ & $\begin{array}{l}\text { http://www.pu } \\
\text { nenvis.nic.in/w } \\
\text { ater/database_i } \\
\text { ndia8.htm }\end{array}$ \\
\hline $\begin{array}{l}\text { UNECE } \\
1994,(\mathrm{ECE} \\
\text { std) Global } \\
\text { sustainable } \\
\text { surface } \\
\text { water }\end{array}$ & $\begin{array}{l}\text { T C: }<50 \\
\text { MPN/100ml } \\
\mathrm{pH}(6.5-9.0), \text { DO } \\
>6 \mathrm{mg} / \mathrm{lit} \\
\text { BOD:5days } 20^{\circ} \\
\text { C, }<2 \mathrm{mg} / \mathrm{l}\end{array}$ & $\begin{array}{l}\text { TC<500MPN/ } \\
\text { 100ml,pH: ( } \\
\text { 6.5-8.5), DO: } \\
>7 \mathrm{mg} / \mathrm{l}, \mathrm{BOD}: \\
\text { 5days } 200 \mathrm{C} \text {, } \\
<3 \mathrm{mg} /\end{array}$ & $\begin{array}{l}\text { TC<5000MPN } \\
\text { /100ml,pH: } \\
6.0-6.3), \mathrm{DO}: \\
>4-6 \mathrm{mg} / \mathrm{l}, \\
\text { COD: } 20^{0} \mathrm{C}, \\
<10-20 \mathrm{mg} / \mathrm{l}\end{array}$ & $\begin{array}{l}\mathrm{pH}:(5.3-6.0) \text {, } \\
\text { DO: }>3-4 \mathrm{mg} / \mathrm{l} \text {, } \\
\text { Free } \mathrm{NH}_{3} \\
\text { 1500-2500, } \\
\text { COD: } 20^{\circ} \mathrm{C} \text {, } \\
<20-30 \mathrm{mg} / \mathrm{l}\end{array}$ & $\begin{array}{l}\mathrm{pH}<5.3, \mathrm{DO}< \\
3,3, \mathrm{Alka} \\
\text { linity<10. COD } \\
>305 . \text { Free NH3 } \\
(\text { as N): }>2500 \text {. } \\
\text { Boron }<2 \mathrm{mg} / \mathrm{l}\end{array}$ & $\frac{\text { www.oecd.org }}{\text { /env/eap }}$ \\
\hline $\begin{array}{l}\text { UNESCO } \\
\text { water } \\
\text { supply } \\
\text { class }\end{array}$ & $\begin{array}{l}\text { pH: } 6.5-8.5 \\
\text { BOD: } 1 \mathrm{mg} / 1 \\
\text { TSS: }<25 \mathrm{mg} / 1 \\
\text { DO: } 7.5\end{array}$ & $\begin{array}{l}\text { pH: } 6.5-8.5 \\
\text { BOD: } 2 \mathrm{mg} / 1 \\
\text { TSS:<25mg/l } \\
\text { DO: } 7.5\end{array}$ & $\begin{array}{l}\text { pH: } 6.5-8.5 \\
\text { BOD: } 3 \mathrm{mg} / 1 \\
\text { TSS:<25mg/l } \\
\text { DO: } 5\end{array}$ & $\begin{array}{l}\text { pH: } 6.5-8.5 \\
\text { BOD:5mg/l } \\
\text { TSS:<50mg/l } \\
\text { DO: } 2\end{array}$ & $\begin{array}{l}\text { pH: } 6.5-8.5 \text {, } \\
\text { BOD:8-10mg/l, } \\
\text { TSS: }<100 \mathrm{mg} / 1 \\
\text { DO: } 2\end{array}$ & $\begin{array}{l}\text { https://www.e } \\
\text { olss .net./sam } \\
\text { ple -chapters } \\
\text { /C07 /E2-19- } \\
\text { 01-02.pd }\end{array}$ \\
\hline $\begin{array}{l}\text { Moldovan } \\
\text { Standards }\end{array}$ & $\begin{array}{l}\text { pH: } 6.5-8.5 \\
\text { BOD:5day20 } \\
\text { C, }<3-5 \mathrm{mg} / 1 \\
\text { COD: } 7 \mathrm{mgO}_{2,1} 1 \\
\text { Fe: } 1 \mathrm{mg} / 1\end{array}$ & $\begin{array}{l}\text { pH: } 6.5-8.5 \\
\text { BOD:5day } 20^{0} \\
\text { C, }<6 \mathrm{mgO} 2 / 1 \text {, } \\
\text { Fe: } 3 \mathrm{mg} / 1\end{array}$ & $\begin{array}{l}\text { pH: } 6.5-8.5 \\
\text { BOD:5day } 20^{0} \\
\text { C, }<3-7 \mathrm{mg} / 1, \\
\text { COD:15-20mg } \\
\text { ll, Fe:5mg/l }\end{array}$ & $\begin{array}{l}\text { pH:6.5-8.5DO } \\
>6 \mathrm{mg} / \mathrm{l}, \mathrm{BOD}: 5 \\
\text { days } 20^{\circ} \mathrm{C},<3 \mathrm{~m} \\
\mathrm{~g} / 1, \mathrm{Fe}: 1 \mathrm{mg} / 1, \mathrm{~T} \\
\text { SS:25-75mg/l }\end{array}$ & $\begin{array}{l}\text { pH: } 6.5-8.5 \\
\text { BOD:5days } 20^{0} \\
\text { C, }<6 \mathrm{mg} / 1 \\
\text { Fe: } 1 \mathrm{mg} / 1\end{array}$ & $\begin{array}{l}\text { http://www.oe } \\
\text { cd.org/envir } \\
\text { onment/ } \\
\text { outreach/3812 } \\
\text { 0922.pdf }\end{array}$ \\
\hline
\end{tabular}

For finding the quality of water different test needed in general are (Temp, EC, pH, DO, and TDS), nutrients for aqua habitats $\left(\mathrm{NH}_{3}\right.$, oxides of $\mathrm{N}_{2}$ and total $\mathrm{P}$ ), Biochemical matters (BOD, COD, Total coliforms), major ions such as $\mathrm{Ca}^{++}, \mathrm{Mg}^{++}, \mathrm{Na}^{+}, \mathrm{K}^{+}, \mathrm{CO}_{2}, \mathrm{Cl}_{2}, \mathrm{SO}_{4}{ }^{++}, \mathrm{HCO}_{3}{ }^{-}$, and their trend during different seasons in an year. Similarly the concentration of metals Chromium total $\left(\mathrm{Cr}^{3++} \mathrm{Cr}^{6+}\right)$, and metaloids and REE's should be evaluated to establish the water to be fit for human use.

\section{Location and Sampling:-}

The disturbed soil samples were collected as a lump dug by a shovel clearing the area from any derbies. The depth of soil from the surface was $15 \mathrm{~cm}$ below ground level from 15 random locations within the sampling area. The samples were mixed together in a clean container and about one $\mathrm{kg}$ of sample was collected in a polythene bag and brought to laboratory for study Fig 7. 
It is required that the samples to be collected is small in quantity but well representing the whole water body so that it should retain its original characters with least significant changes, flawless water quality parametric valuation, maintaining the status and the trends in water quality, well representative samples, prohibited zone for men and animals like cattle bathing, mass bathing, Dhobi Ghats and cattle tress passing etc.

The sampling ponds are so chosen that the yield samples are well representative of the study area covering the inlet, central and remote outlet (if any), integrated sampling out of grab, composite and integrated sampling methods, the Dry season sampling as there is no runoff before conducting tests.

The nonreactive sampling glass nonreactive bottles are used to collect samples without bed materials and floating materials and algae of adequate capacity and free of contamination. Preservation of the collected samples in the laboratory was as per CPCB norms. Highly unsteady parameters such as temperature, pH, transparency, DO, etc. are observed inset or immediately after reaching the laboratory.

\section{Recommended standards and impact:-}

EPA (WHO) has proposed drinking water standard (5 ppb) which is > the feasible level (3 ppb) which is the Safe Drinking Water Act (SDWA).The SWD of a pond or treated water from the effluents of hospital can be determined by its physical, Chemical, presence of heavy metals and rare earth metals (REE) and biological parameters. The different standards and their tolerable limits including their method of determination are fixed by World health organization (WHO), United state environmental protection agency (USEPA), Indian standards by Central Pollution Control Board (CPCB) Table 1.

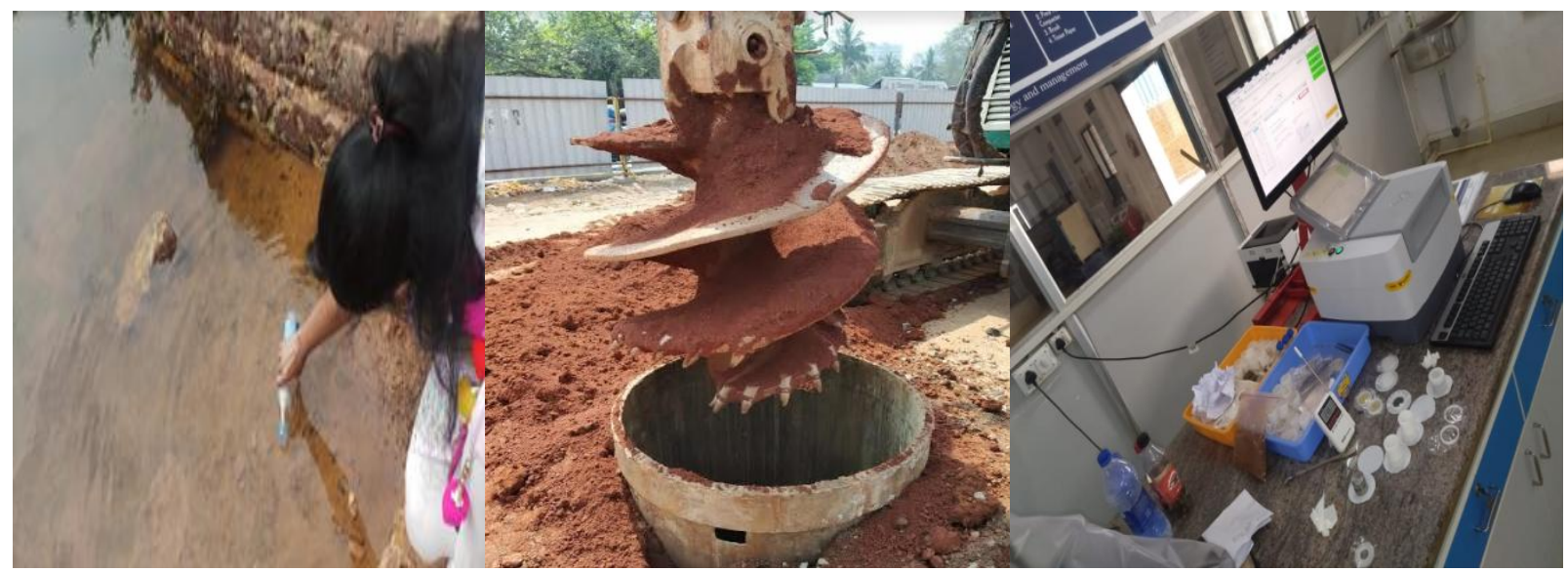

Fig 7:-Collection of water, soilsamples and analysis by XRF photospectrometer in the laboratory

CPCB has reported that the data validation should be done as follows: i. Total solids $\geq$ TDS, COD $>$ BOD, Total Coli $\geq$ Faecal Coli, Total Iron $\geq \mathrm{Fe}+2, \mathrm{Fe}+3, \mathrm{EC}(\mu \mathrm{S} / \mathrm{cm}) \geq \mathrm{TDS}(\mathrm{mg} / \mathrm{l})$, Total P $\geq \mathrm{PO}-3$ and Total hardness $=\mathrm{Ca}$ hardness + Mg hardness. Few customary links can be established are Some of the more well-known correlations between parameters are: Total dissolved solids Vs. specific conductance, pH vs. carbonate species, pH vs. free metal ionic conc., DO vs. nitrates. Some of the established conclusions are If (a) $\mathrm{pH}<8.3$ then CO3-2 = 0, (b) DO $=0, \rightarrow \mathrm{NO} 3$ - ion $=0$, (c) $\mathrm{DO}>0$, then nitrate $>0$, If $\mathrm{DO}>7 \mathrm{~m}$, then Fe-2 ions $=0$, If nitrite $>0$, then ferrous ions $=$ 0 , If ferrous ions $>0$, then nitrite $=0$. The table shows the standards of the water quality parameters determined by different agencies and their impact on human, fauna (including aqua fauna and avi fauna) MINARS/27/2007-08.

\section{Laterite soil analysis:-}

The soil samples were tagged and coded as Delang(SS-1),Jatni(SS-2),Tangi (SS-3) and Khandagiri from a depth of $5.2 \mathrm{~m}$ (SS-4).The nonmetals, metals, metalloids and rare earth metals were found from the laterite soil samples using XRF spectrometer and the results are given in Table 2 (a), Table 2(b), Table 2(c), Table 2(d) and Table 2(e).

\section{A-Alkali/Alkaline earth metals}

\begin{tabular}{|l|l|l|l|l|l|l|}
\hline$\#$ & Oxides of element & formula & $\begin{array}{l}\text { Delang Soil } \\
\text { ( SS-1)ppm }\end{array}$ & $\begin{array}{l}\text { Jatni (SS-2) } \\
\text { ppm }\end{array}$ & $\begin{array}{l}\text { Tangi(SS- } \\
\text { 3)ppm }\end{array}$ & $\begin{array}{l}\text { Khandagiri (5.20m } \\
\text { deep) SS-4 }\end{array}$ \\
\hline
\end{tabular}




\begin{tabular}{|l|l|l|l|l|l|l|}
\hline 1 & Aluminum & $\mathrm{Al}_{2} \mathrm{O}_{3}$ & $24.143 \%$ & $26.411 \%$ & $22.569 \%$ & $21.906 \%$ \\
\hline 2 & Silicon & $\mathrm{SiO}_{2}$ & $55.830 \%$ & $50.551 \%$ & $58.964 \%$ & $49.245 \%$ \\
\hline 3 & Ferric & $\mathrm{Fe}_{2} \mathrm{O}_{3}$ & $14.202 \%$ & $17.164 \%$ & $12.026 \%$ & $22.674 \%$ \\
\hline 4 & Phosphorus & $\mathrm{P}_{2} \mathrm{O}_{5}$ & $0.556 \%$ & $0.573 \%$ & $0.527 \%$ & $0.964 \%$ \\
\hline 5 & Sulphite & $\mathrm{SO}_{3}$ & 0.0 & 692.2 & 649.3 & 0.0 \\
\hline 6 & Chlorine & $\mathrm{Cl}$ & 455.1 & 698.5 & 447.3 & 995.2 \\
\hline 7 & Potassium & $\mathrm{K}_{2} \mathrm{O}$ & $2.542 \%$ & $2.474 \%$ & $2.559 \%$ & $2.399 \%$ \\
\hline 8 & Calcium & $\mathrm{CaO}$ & $0.557 \%$ & $0.873 \%$ & $0.904 \%$ & $0.451 \%$ \\
\hline 9 & Rubidium & $\mathrm{Rb} O$ & 223.5 & 211.5 & 189.3 & $287.0 \mathrm{ppm}$ \\
\hline 10 & Strontium & $\mathrm{SrO}$ & 69.1 & 114.2 & 76.2 & $88.6 \mathrm{ppm}$ \\
\hline 11 & Barium & $\mathrm{BaO}$ & 611.5 & 404.5 & 332.6 & $382.4 \mathrm{ppm}$ \\
\hline
\end{tabular}

The soil samples of the patch of laterite in Khordha patch is different than Koraput, Sundargarh and Jajpur areas. Kale et al 2016, has reported that the serpentine convert to montmorillonite, aluminous goethite, and quartz but bauxite group is absent and presence of $\mathrm{Ni}$ and $\mathrm{Fe}$ in Sukinda valleys of Singhbhum cartoon. Similarly the laterite ranges of Koraput hills major constituent is bauxite and that of Gandhamardan hills is Fe dominated.

Table 2(b): the ratio in concentration for $\mathrm{Al}$, Si and $\mathrm{Fe}$ in different samples collected

\begin{tabular}{|c|c|c|c|c|c|}
\hline $\begin{array}{c}\text { The elemet } \\
\text { oxide }\end{array}$ & $\begin{array}{c}\text { Ratio in Delang } \\
\text { Soil (\%) }\end{array}$ & $\begin{array}{c}\text { Ratio in Jatni } \\
\text { Soil (\%) }\end{array}$ & $\begin{array}{c}\text { Ratio in Tangi } \\
\text { Soil (\%) }\end{array}$ & $\begin{array}{c}\text { Ratio in Khandagiri } \\
5,2 \mathrm{~m} \text { deep soil (\%) }\end{array}$ & $\begin{array}{c}\text { Average } \\
\text { values }\end{array}$ \\
\hline $\mathrm{Al}: \mathrm{Si}$ & $43.24 \%$ & $52.25 \%$ & $38.28 \%$ & $44.48 \%$ & $44.56 \%$ \\
\hline $\mathrm{Fe}: \mathrm{Si}$ & $25.44 \%$ & $33.95 \%$ & $20.40 \%$ & $46.04 \%$ & $31.46 \%$ \\
\hline $\mathrm{Fe}: \mathrm{Al}$ & $58.82 \%$ & $64.99 \%$ & $53.29 \%$ & $103.51 \%$ & $70.15 \%$ \\
\hline
\end{tabular}

It is observed that the $\mathrm{Si}$ content reduces and Fe content increases as we go deeper. The average values in $\mathrm{Al}: \mathrm{Si}$,

Fe:Si and Fe:Al are $44.56 \%, 31.46 \%$ and $70.15 \%$ only as in Table 2(b)

\section{B-Transition and other metal oxides}

\begin{tabular}{|l|l|l|l|l|l|l|}
\hline$\#$ & Oxides of element & formula & $\begin{array}{l}\text { Delang Soil } \\
(\mathrm{SS}-1) \mathrm{ppm}\end{array}$ & $\begin{array}{l}\text { Jatni (SS-2) } \\
\text { ppm }\end{array}$ & $\begin{array}{l}\text { Tangi (SS-3) } \\
\text { ppm }\end{array}$ & $\begin{array}{l}\text { Khandagiri (5.20m } \\
\text { deep SS-4 }\end{array}$ \\
\hline 1 & Vanadium & $\mathrm{V}_{2} \mathrm{O}_{5}$ & 489.8 & 545.7 & 493.2 & $707.5 \mathrm{ppm}$ \\
\hline 2 & Titanium & $\mathrm{TiO}_{2}$ & 1.401 & $1.257 \%$ & 1.676 & $1.690 \%$ \\
\hline 3 & Chromium & $\mathrm{Cr}_{2} \mathrm{O}_{3}$ & 471.9 & 610.9 & 342.9 & $543.5 \mathrm{ppm}$ \\
\hline 4 & Manganese & $\mathrm{MnO}$ & $0.194 \%$ & 851.7 & $0.228 \%$ & $216.5 \mathrm{ppm}$ \\
\hline 5 & Ferric & $\mathrm{Fe}_{2} \mathrm{O}_{3}$ & $14.202 \%$ & $17.164 \%$ & $12.026 \%$ & $22.674 \%$ \\
\hline 6 & Nickel oxide & $\mathrm{NiO}$ & 179.0 & 185.5 & 153.9 & $334.9 \%$ \\
\hline 7 & Gallium & $\mathrm{Ga}_{2} \mathrm{O}_{3}$ & 50.8 & 68.6 & 50.1 & $103.7 \mathrm{ppm}$ \\
\hline 8 & Arsenic & $\mathrm{As}_{2} \mathrm{O}_{3}$ & 0.0 & 0.0 & 0.0 & $46.0 \mathrm{ppm}$ \\
\hline 9 & Yttrium & $\mathrm{Y}_{2} \mathrm{O}_{3}$ & 68.8 & 51.7 & 61.7 & $78.3 \mathrm{ppm}$ \\
\hline 10 & Zirconium & $\mathrm{ZrO}_{2}$ & 961.4 & 884.3 & 0.117 & $0.150 \%$ \\
\hline 11 & Niobium & $\mathrm{Nb}_{2} \mathrm{O}_{5}$ & 40.1 & 39.0 & 36.0 & $78.0 \mathrm{ppm}$ \\
\hline 12 & Stannic & $\mathrm{SnO}_{2}$ & nil & nil & 97.0 & $238.3 \mathrm{ppm}$ \\
\hline 13 & Iridium & $\mathrm{IrO}_{2}$ & 0.0 & 0.0 & 7.1 & $8.0 \mathrm{ppm}$ \\
\hline 14 & Lead & $\mathrm{PbO}$ & 98.8 & 167.8 & 81.2 & $142.6 \mathrm{ppm}$ \\
\hline
\end{tabular}

On analysis of the oxides of transition and other metal/metalloids the content of harmful and toxic ingradients like

$\mathrm{Fe}$, Chrome and Nickel, Zirconium and lead are present in excess and above the permissible limits.

\section{C-Rare earth metals}

\begin{tabular}{|l|l|l|l|l|l|l|}
\hline$\#$ & $\begin{array}{l}\text { Oxides of } \\
\text { element }\end{array}$ & formula & $\begin{array}{l}\text { Delang Soil } \\
(\mathrm{SS}-1) \mathrm{ppm}\end{array}$ & $\begin{array}{l}\text { Jatni (SS-2) } \\
\text { ppm }\end{array}$ & $\begin{array}{l}\text { Tangi(SS- } \\
\text { 3)ppm }\end{array}$ & $\begin{array}{l}\text { Khandagiri (5.2m) } \\
\text { deep SS-4 }\end{array}$ \\
\hline 1 & Europium & $\mathrm{Eu}_{2} \mathrm{O} 3$ & $0.158 \%$ & 991.4 & 843.4 & $814.6 \mathrm{ppm}$ \\
\hline 2 & Yttrium & $\mathrm{Yb}_{2} \mathrm{O} 3$ & 36.6 & 55.9 & 61.8 & $144.7 \mathrm{ppm}$ \\
\hline 3 & Rhenium & $\mathrm{Re}$ & 0.0 & 0.0 & 0.9 & $6.4 \mathrm{ppm}$ \\
\hline 4 & Thorium & $\mathrm{ThO}_{2}$ & nil & nil & 76.5 & nil \\
\hline
\end{tabular}




\begin{tabular}{|l|l|l|l|l|l|l|}
\hline 5 & Lutetium & $\mathrm{Lu}_{2} \mathrm{O}_{3}$ & 183.2 & 170.3 & nil & nil \\
\hline
\end{tabular}

The lanthanides and actinides (REE's) present in the soil are Eu, $\mathrm{Yb}$ and $\mathrm{Lu}$ which are less toxic.

The water analysis studies:-

Water samples are collected from sites are:WS-1: Water sample collected from laterite area of Jatni, WS2: water sample collected from laterite area of Tangi, WS-3: CUTM pond water in laterites, Jatni, WS4: water sample collected from Delang laterite area,WS5: water sample from Tangi laterite mines, and also compared with the sea water WS-6and sweet water areas of Puri as WS-7. Sea water and fresh water of Puri is considered as a compare standards fixed by WHO and ECE for waterquality standards for classification of freshwater for the sustenance of aquatic life is given in Table 3.a

Table 3(a): ECE Water quality standards for classification of freshwater for the sustenance of aquatic life

\begin{tabular}{|l|l|l|l|l|l|l|}
\hline Parameters & Unit/Ponds & Class I & Class II & Class III & Class VI & Class V \\
\hline DO & $\mathrm{mg} / 1$ & $>7$ & 7 to 6 & 6 to 4 & 4 to 3 & $<3$ \\
\hline COD-Mn & $\mathrm{mgO} / \mathrm{l}$ & $<3$ & 3 to 10 & 10 to 20 & 20 to 30 & $>30$ \\
\hline Total $\mathrm{P}$ & $\mathrm{mg} / 1$ & $1-<10$ & 10 to 25 & $25-50$ & 50 to 125 & $>125$ \\
\hline Total N & $\mu \mathrm{g} / 1$ & $<300$ & 300 to 750 & 750 to 1500 & 1500 to 2500 & $>2500$ \\
\hline Alkalinity & $\mathrm{mg} \mathrm{CaCO} / \mathrm{l}$ & $>200$ & $100-200$ & $100-20$ & $20-10$ & $<10$ \\
\hline Metals/Metalloids & & & & & \\
\hline Aluminum $(\mathrm{Al})$ & $\mu \mathrm{g} / 1 \mathrm{pH}-6.5$ & $<1.6$ & $1.6-3.2$ & $3.2-5.5$ & $5.5-75$ & $>75$ \\
\hline Arsenic $(\mathrm{As})$ & $\mu \mathrm{g} / 1$ & 3 to 10 & 10 to 100 & 100 to 190 & $190-360$ & $>360$ \\
\hline Cadmium $(\mathrm{Cd})$ & $\mu \mathrm{g} / 1$ & 0.07 & 0.07 to 0.53 & $0.53-1.1$ & 1.1 to 3.9 & $>3.9$ \\
\hline Chromium $(\mathrm{Cr})$ & $\mu \mathrm{g} / 1$ & 1 to 6 & 6 to 11 & 11 to 16 & $>16$ \\
\hline Copper $(\mathrm{Cu})$ & $\mu \mathrm{g} / 1$ & 2 to 7 & 7 to 12 & 12 to 18 & $>18$ \\
\hline Lead $(\mathrm{Pub})$ & $\mu \mathrm{g} / 1$ & $<2$ & 0.1 to 1.6 & 1.6 to 3.2 & $3.2-82$ & $>82$ \\
\hline Mercury $(\mathrm{Hg})$ & $\mu \mathrm{g} / 1$ & $<0.1$ & $0.003-0.007$ & $0.007-0.012$ & $0.012-2.4$ & $>2.4$ \\
\hline Nickel $(\mathrm{Ni})$ & $\mu \mathrm{g} / 1$ & $15-87$ & $87-160$ & $160-1400$ & $>1400$ \\
\hline Zinc $(\mathrm{Zn})$ & $\mu \mathrm{g} / 1$ & $<15$ & $45-77$ & $77-110$ & $110-120$ & $>120$ \\
\hline
\end{tabular}

andWHO:https://www.who.int/water_sanitation_health/resourcesquality/wpcchap2.pdf

The aquatic ecosystems has multifaceted interface between their physical, chemical and biochemical cycles, human interventions. The water chemistry favors or adversely upset species of aquatic flora, fauna and avifauna. So water chemistry plays vital role to sustain these aquatic lives. The bio-chemical properties and mineralogical properties are studied in the Laboratories of Centurion University of Technology and Management and the observed results are given in Table 3.b, Table 3 .c, Table 3 .d, Table 3. e and Table $3 \mathrm{f}$. showing properties like Physico chemical, Alkaline and alkali ions, Transison metals/metalloids, REE's and Biochemical properties of water. The physic chemical properties of sea water at nearest station Puri and the sweet water areas of Puri was chosen to have a better comparison with the water within the laterite mines

Table 3.b:Physicochemical properties of Water sample collected (analyses of physical, chemical and biological parameters, $\underline{\text { http://wgbis.ces.iisc.ernet.in/energy/monograph1/casepage1.html }}$

\begin{tabular}{|l|l|l|l|l|l|l|l|l|l|l|}
\hline $\begin{array}{l}\text { Physical } \\
\text { prop. }\end{array}$ & unit & $\begin{array}{l}\text { Instrumen } \\
\text { ts used }\end{array}$ & $\begin{array}{l}\text { IS:105 } \\
00 / 12\end{array}$ & WS-1 & WS-2 & WS-3 & WS-4 & WS-5 & WS-6 & WS-7 \\
\hline Colour & Hazen & Visual & $5-15$ & $\begin{array}{l}\text { faint } \\
\text { yellow }\end{array}$ & $\begin{array}{l}\text { faint } \\
\text { yellow }\end{array}$ & $\begin{array}{l}\text { colourl } \\
\text { ess }\end{array}$ & $\begin{array}{l}\text { colourl } \\
\text { ess }\end{array}$ & $\begin{array}{l}\text { colourl } \\
\text { ess }\end{array}$ & $\begin{array}{l}\text { colourl } \\
\text { ess }\end{array}$ & $\begin{array}{l}\text { colourl } \\
\text { ess }\end{array}$ \\
\hline Odour & no unit & smell & $\begin{array}{l}\text { Agreea } \\
\text { ble }\end{array}$ & $\begin{array}{l}\text { agreea } \\
\text { ble }\end{array}$ & $\begin{array}{l}\text { agreea } \\
\text { ble }\end{array}$ & $\begin{array}{l}\text { agreea } \\
\text { ble }\end{array}$ & $\begin{array}{l}\text { agreea } \\
\text { ble }\end{array}$ & $\begin{array}{l}\text { agreea } \\
\text { ble }\end{array}$ & $\begin{array}{l}\text { agreea } \\
\text { ble }\end{array}$ & $\begin{array}{l}\text { agreea } \\
\text { ble }\end{array}$ \\
\hline Taste & no unit & Taste & Normal & Normal & Normal & Normal & Normal & Normal & Normal & Normal \\
\hline pH & no unit & pH meter & $6.5-8.5$ & 6.65 & 6.55 & 6.75 & 6.63 & 6.67 & 7.78 & 6.60 \\
\hline
\end{tabular}




\begin{tabular}{|l|l|l|l|l|l|l|l|l|l|l|}
\hline Temp. & celsius & $\begin{array}{l}\text { Hg thermo } \\
\text { meter }\end{array}$ & $\begin{array}{l}\text { above } \\
25^{0} \mathrm{C}\end{array}$ & 28.4 & 28.6 & 28 & 29 & 30 & 28.5 & 28.9 \\
\hline Turbidity & $\mathrm{NTU}$ & $\begin{array}{l}\text { turbidity } \\
\text { meter }\end{array}$ & $1-5$ & 3.8 & 3.6 & 2.3 & 4.4 & 4.8 & 2.3 & 2.6 \\
\hline Hardness & $\mathrm{mg} / \mathrm{l}$ & $\begin{array}{l}\text { titration } \\
\text { method }\end{array}$ & $\begin{array}{l}200- \\
600\end{array}$ & 1350 & 1270 & 1300 & 1255.6 & 1274.5 & 1100 & 1000 \\
\hline TSS & $\mathrm{mg} / \mathrm{l}$ & Balance & 100 & 2.5 & 2.1 & 0.89 & 2.3 & 1.99 & 0.05 & 0.04 \\
\hline Alkalinity & $\mathrm{mg} / \mathrm{l}$ & titrimetric & $30-90$ & 49 & 48.8 & 33 & 36.6 & 34.3 & 29.8 & 27.9 \\
\hline TDS & $\mathrm{mg} / \mathrm{l}$ & $\begin{array}{l}\text { TDS } \\
\text { meter }\end{array}$ & $\begin{array}{l}164- \\
500\end{array}$ & 305 & 340 & 205 & 340 & 303 & 170 & 178 \\
\hline EC & $\begin{array}{l}\text { milimho } \\
\text { /cm }\end{array}$ & $\begin{array}{l}\text { EC meter } \\
\text { digital }\end{array}$ & $\begin{array}{l}50- \\
1500\end{array}$ & 784 & 788 & 531 & 750 & 660 & 505 & 510 \\
\hline
\end{tabular}

The physical sample of water from the ponds of summer were analyzed during summer season it can be inferred that the $\mathrm{pH}$, Turbidity, Alkalinity and EC are within permissible limits whereas TDS, alkalinity is agreeable but hard ness is higher than the permissible limit.

Table 3.c: Alkali/alkaline earth metals (from $5 \mathrm{ml}$ sample)

\begin{tabular}{|l|l|l|l|l|l|l|l|l|l|}
\hline$\#$ & Elements & Symbol & WS-1 & WS-2 & WS-3 & WS-4 & WS-5 & WS-6 & WS-7 \\
\hline & Unit & \% or ppm & $\begin{array}{l}\% \text { or } \\
\text { ppm }\end{array}$ & $\begin{array}{l}\% \text { or } \\
\text { ppm }\end{array}$ & $\begin{array}{l}\% \text { or ppm } \\
\text { o or } \\
\text { ppm }\end{array}$ & $\begin{array}{l}\text { \% or ppm } \\
\text { ppm }\end{array}$ \\
\hline 1 & Aluminium & $\mathrm{Al}$ & nil & nil & nil & nil & nil & nil & nil \\
\hline 2 & Silicon & $\mathrm{Si}$ & 446.3 & 0.130 & 0.112 & 430.3 & 335.6 & 663.8 & 26.740 \\
\hline 3 & Phosphorus & $\mathrm{P}$ & 580.1 & 578.3 & 597.1 & 567.5 & 505.7 & 552.6 & $39.68 \%$ \\
\hline 4 & Sulphur & $\mathrm{S}$ & nil & 216.0 & 151.2 & 150.1 & nil & 717.0 & nil \\
\hline 5 & Chlorine & $\mathrm{Cl}$ & 306.9 & 249.6 & 201.6 & 189.3 & 167 & $1.975 \%$ & $7.986 \%$ \\
\hline 6 & Potassium & $\mathrm{K}$ & nil & nil & nil & nil & nil & 416.0 & nil \\
\hline 7 & Calcium & $\mathrm{Ca}$ & 257.0 & 226.2 & 713.2 & 221.0 & 216.8 & 591.8 & $15.66 \%$ \\
\hline 8 & Rubidium & $\mathrm{Rb}$ & nil & nil & nil & nil & nil & nil & nil \\
\hline 9 & Strontium & $\mathrm{Sr}$ & nil & nil & nil & nil & nil & 6.6 & nil \\
\hline
\end{tabular}

Table 3 .d: Transition metals (from $5 \mathrm{ml}$ sample)

\begin{tabular}{|l|l|l|l|l|l|l|l|l|l|}
\hline$\#$ & Elements & & WS-1 & WS-2 & WS-3 & WS-4 & WS-5 & WS-6 & WS-7 \\
\hline & Unit & Symbol & \% or ppm & $\begin{array}{l}\text { \% or } \\
\text { ppm }\end{array}$ & $\begin{array}{l}\text { \% or } \\
\text { ppm }\end{array}$ & $\begin{array}{l}\% \text { or } \\
\text { ppm }\end{array}$ & $\begin{array}{l}\text { \% or } \\
\text { ppm }\end{array}$ & \% or ppm & $\%$ or ppm \\
\hline 1 & Titanium & Ti & 0.00 & nil & nil & nil & nil & 9.4 & nil \\
\hline 2 & Manganese & $\mathrm{Mn}$ & 0.0 & 0.0 & 11.3 & nil & nil & 1.5 & 0.0 \\
\hline 3 & Iron & $\mathrm{Fe}$ & 46.3 & 33.8 & 42.0 & 33.6 & 38.0 & 31.9 & 3.748 \\
\hline 4 & Stannic & $\mathrm{Sn}$ & nil & 38.2 & 54.0 & 110.4 & 150.5 & 31.5 & 2.025 \\
\hline
\end{tabular}

Table 3.e: Rare earth metals (from $5 \mathrm{ml}$ sample)

\begin{tabular}{|l|l|l|l|l|l|l|l|l|l|}
\hline$\#$ & Elements & $\begin{array}{l}\text { Symbol } \\
\text { s }\end{array}$ & WS-1 & WS-2 & WS-3 & WS-4 & WS-5 & WS-6 & WS-7 \\
\hline Unit & Symbol & $\%$ or ppm & $\begin{array}{l}\% \text { or } \\
\text { ppm }\end{array}$ & $\begin{array}{l}\% \text { or } \\
\text { ppm }\end{array}$ & $\begin{array}{l}\% \text { or } \\
\text { ppm }\end{array}$ & $\begin{array}{l}\% \text { or } \\
\text { ppm }\end{array}$ & \% or ppm & $\begin{array}{l}\% \text { or } \\
\text { ppm }\end{array}$ \\
\hline 1 & Gadolinium & Gd & 23.6 & nil & nil & 11.6 & nil & nil & nil \\
\hline 2 & Erbium & Er & nil & 67.6 & nil & nil & nil & nil & nil \\
\hline 3 & Europium & Eu & nil & nil & nil & nil & nil & 22.0 & 1.343 \\
\hline 4 & Samarium & Sm & nil & nil & nil & nil & nil & nil & 2.821 \\
\hline
\end{tabular}


Table 3.f: -Biochemical parameters:

\begin{tabular}{|l|l|l|l|l|l|l|l|l|l|}
\hline$\#$ & parameter & $\begin{array}{l}\text { Permissibl } \\
\text { e limit }\end{array}$ & $\begin{array}{l}\text { Khandag } \\
\text { iri (s1) } \\
\text { ppm }\end{array}$ & $\begin{array}{l}\text { Golabai } \\
(\mathrm{s} 2) \mathrm{ppm}\end{array}$ & $\begin{array}{l}\text { Jatni } \\
(\mathrm{s} 3) \mathrm{ppm}\end{array}$ & $\begin{array}{l}\text { Delang } \\
(\mathrm{s} 4) \mathrm{ppm}\end{array}$ & $\begin{array}{l}\text { Tangi } \\
(\mathrm{s} 5) \mathrm{ppm}\end{array}$ & $\begin{array}{l}\text { seawater, } \\
\text { puri (s6) } \\
\mathrm{ppm}\end{array}$ & $\begin{array}{l}\text { Potable } \\
\text { Puri } \\
(\mathrm{s} 7) \mathrm{ppm}\end{array}$ \\
\hline 1 & DO & $0-18$ & 21 & 18.5 & 16.5 & 18 & 18.5 & 2.2 & 2.4 \\
\hline 2 & BOD & $0-100$ & 70 & 95 & 46 & 80 & 85 & 20 & 25 \\
\hline 3 & COD & 250 & 289.6 & 288.5 & 236 & 267.8 & 244.5 & 376 & 166.9 \\
\hline 4 & Algae & Undesired & present & Absent & grown & Absent & present & grown & absent \\
\hline 5 & Tadpole & Desired & present & Present & present & present & Absent & Absent & Absent \\
\hline 6 & Fish & Desired & present & absent & absent & present & absent & present & present \\
\hline 7 & Mollusca & Desired & present & present & present & present & present & present & Present \\
\hline 8 & $\begin{array}{l}\text { Hydrophyte } \\
\text { s }\end{array}$ & Desired & Present & Present & Present & Present & present & Absent & present \\
\hline
\end{tabular}

The biochemical parameters such as DO, BOD and COD of water bodies in laterite mines observed to be on higher side than that of sea water and fresh water in alluvial stretches of coastal districts. The maximum tolerable DO permissible according to CPCB norms

\section{Analysis and Discussion:-}

The geo-bio chemistry of the water bodies:-

The conditions of geology, ecosystem, and the water chemistry is organized either by natural processes (soil, rock, hydrologic systems and topography) or anthropogenic activities by mining, land use, land cover, industrialization, urbanization and finally the social and economic status around the area. The natural geological processes may be difficult to control but human activities can be curtailed by detection and proper administration of problems by knowing the changes in the environment.

The water quality parameters of the stagnated water bodies in laterite mines were studied and related flora and fauna of the area were verified. Temperature fluctuations are abnormal in the area between Day and night temperatures. It was found that the laterite area is barren, no grass, the water bodies have traces of aqua habitats in the stagnated water and some IAS fauna's are seen in the active mines area. The area is used for open defecation by the local persons and used for bathing when there is water crisis in summer. The bovines do not drink the water and the water bodies is poor in fish growth and even snails, larva of frogs are not commonly seen.

pH:Peuranen S., et al $1994^{[38]}$, Krishna P. V. et al., 2012 $2^{[39]}$, Slaninova et al 2014 ${ }^{[37]}$ had also observed that presence of excess Al and Fe in water and soil causes damage to kidney, liver, spleen, the parenchymatous tissues of the fish fauna in ponds in the laterite mines even at $\mathrm{pH}$ values between 6-7. Studies reveal that very high $(>9.5)$ or very low $(<4.5)$ of $\mathrm{pH}$ values are in appropriate for servival for most aquatic organisms. Young and early aquatic habitats including aquatic insects are extremely sensitive to $\mathrm{pH}$ ranges <4.5.and causes death at such low pH valueshttps://www.yokogawa.com/in/library/resources/application-notes/ph-infish-farming.

DO: Fishes and other benthic and floating aquatic plants/animals respirate oxygen dissolved in water into their bloodstream using gills, whereas inland animals do so with lungs from the atmosphere. The lower limit of is 5pm may put fishes under stress and even DO values at 1-2 ppm cause fishes to suffocate and die. When DO values are high or at high saturation condition of DO in a pond during day is followed by low oxygen concentration during night specially morning creating Hypoxic (i.e. low oxygen) settings. This may cause water quality problems and the fishes and other aquatic fauna get suffocated and may not survive reported by Barbara Robson, Research Scientist (Modeling Aquatic Ecosystems), 2017..Wiebe A. H,.1933 made a series of experiments on fishes at oxygen super-saturation of water and observed that over doses of DO cause suffocation to fishes. The upper limit of DO is $14 \mathrm{ppm}$ or $\mathrm{mg} / \mathrm{l}$ but when DO level exceeds $14 \mathrm{mg} / \mathrm{l}$ the fishes shall suffer from gas bubble disease, where the bubbles block the flow of blood through blood vessels causing death of fishes (to be verified).

The huge quantity of water in the ponds in laterite mines area are of minimal use from drinking, bathing, aquaculture, irrigation and economic uses like recreational uses. The clear water goes wasted except 
recharging the ground water. It is high time when minimum availability of water for human use, to treat the water and reuse for human benefits knowing the demography and hydrology of the area, chemistry of the rock, soil and water, availability of safe water in and around. Water quality of ponds are governed by uncontrolled natural processes (soil, rock and climate) and anthropogenic influences which can be controlled (Table 4).

Table 4: Fact sheet summarizing the important human and climatic factors controlling WQ parameters and pond uses

\begin{tabular}{|l|l|l|l|l|}
\hline Parameters & $\begin{array}{l}\text { Recommended } \\
\text { limit/growth rate }\end{array}$ & Observed during study & suitability & Remarks \\
\hline Population & $\begin{array}{l}667 / \mathrm{Km}^{2}(\text { census } \\
2001 \mathrm{Khurdha})\end{array}$ & $\begin{array}{l}800 / \mathrm{Km}^{2}(\text { Census } 2011 \\
\text { Khurdha) }\end{array}$ & Suitable climate & $\approx 24.89$ lakhs \\
\hline Rainfall & $1449.1 \mathrm{~mm}$ & 1685.2 & Increasing trend & $\begin{array}{l}\text { More ponding zone in } \\
\text { laterite mines }\end{array}$ \\
\hline Temperature & 27.2 & $\begin{array}{l}\text { Av summer max } 41.4^{0} \& \\
\text { min } 9.5^{\circ} \mathrm{C}\end{array}$ & $\begin{array}{l}\text { Unsuitable in } \\
\text { summer }\end{array}$ & Rising trend in the state \\
\hline Colour & clear & $\begin{array}{l}\text { Muddy in rain and clear } \\
\text { in rest period }\end{array}$ & Little iron smell & $\begin{array}{l}\text { Colour changes with } \\
\text { waste filling }\end{array}$ \\
\hline $\begin{array}{l}\text { Ground water } \\
\text { variation }\end{array}$ & $\begin{array}{l}\text { Max } 7.27 \mathrm{~m} \text { bgl }(\mathrm{Av} \\
\text { GWT Tangi) }\end{array}$ & $\begin{array}{l}\text { Max rise } 0.18 \mathrm{~m} / \mathrm{yr} \& \\
\text { Fall } 0.006 \mathrm{~m} / \mathrm{yr}\end{array}$ & $\begin{array}{l}\text { Rising trend } \\
(2001-2011)\end{array}$ & $\begin{array}{l}\text { Consolidated/ } \\
\text { unconsolidated } \\
\text { formations }\end{array}$ \\
\hline
\end{tabular}

The Ponds stores water within the ditches and even make large water bodies of 10 to $15 \mathrm{Ha}$. It is observed in ponds formed old mines have little aqua fauna and aquatic plants.

\section{Chemical parameters:-}

The ponds formed in mines within laterites rocks exhibits divergent chemical compositions and so also contrasting physical, chemical and biological properties. The aluminum and Iron ratios are of high ratios but mostly same of laterites on mafic and ultramafic rocks as the underlying parent rock depending upon the underlying rock. The proportion of Fe increases as we go deep. The exposure, leaching and hardening properties are the causes of poor agriculture and vegetationLukowicz M., $1976^{[41]}$.

Alipore $\mathrm{H}$ et al, $2016^{[42]}$ have reported that $\mathrm{Fe}$ is essential for fish growth in fresh water and metal contain in tissue and gills of various fishes are different. The trend of concentration of metals are $\mathrm{Fe}>\mathrm{Zn}>\mathrm{Cu}$ $>$ As. In the present study it is found that the order prevails and the concentration of various metals, metalloids and REE's present in laterite mines water. The water quality parameters that affect the human and the aqua fauna is given in table 5 (A), 5 (B) and 5 (C).

\section{5 (A) - Alkali and alkaline earth metals}

\begin{tabular}{|l|l|l|l|l|}
\hline Elements & Average & Effect on human & Effect on fishes & $\begin{array}{l}\text { Remark(study } \\
\text { area) }\end{array}$ \\
\hline $\begin{array}{l}\text { Aluminum } \\
(\mu \mathrm{gm} / \mathrm{l})\end{array}$ & 0.0 & $\begin{array}{l}\text { Alzheimer's disease, } \\
\text { osteomalacia, normal renal } \\
\text { dysfunction }\end{array}$ & $\begin{array}{l}\text { Gill tissue necrosis, parenchymatousdamage } \\
\text { to tissue ,increase activity of transaminase in } \\
\text { blood plasma. }\end{array}$ & $\begin{array}{l}\text { absent in laterite } \\
\text { mines water but } \\
\text { in soils }\end{array}$ \\
\hline $\begin{array}{l}\text { Silicon } \\
(\mu \mathrm{gm} / \mathrm{l})\end{array}$ & 242.488 & $\begin{array}{l}\text { Bone tendons aorta, liver } \\
\text { and kidney deposits } \\
\text { Alzheimer's chronic } \\
\text { bronchitis }\end{array}$ & $\begin{array}{l}\text { Damage in gill, liver, brain tissue, } \\
\text { upliftment of gill epithelium with } \\
\text { mucousdeposits., vacuolization in gill } \\
\text { arches,curling of 2ndry lamella, } \\
\text { segmentation of Hepato-cytes, spindle } \\
\text { shaped nucleus and necrosis. }\end{array}$ & Present \\
\hline $\begin{array}{l}\text { Phosphorus } \\
(\mu \mathrm{gm} / \mathrm{l})\end{array}$ & 565.74 & $\begin{array}{l}\text { Respiratory tract infection } \\
\text { coughing in humans severe } \\
\text { burns }\end{array}$ & $\begin{array}{l}\text { Phosphate has the potential to cause } \\
\text { increased algal growth leading to } \\
\text { eutrophication in the aquatic environment }\end{array}$ & $\begin{array}{l}\text { High conc. of } \\
\text { phosphorus }\end{array}$ \\
\hline Sulphur & 103.46 & Neurological effects, blood & Immune suppression, low metabolism, & Present \\
\hline
\end{tabular}




\begin{tabular}{|l|l|l|l|l|}
\hline$(\mu \mathrm{gm} / \mathrm{l})$ & & $\begin{array}{l}\text { circulation problem, cardiac } \\
\text { disorder, generative disorder } \\
\text { asphyxia, dermatitis }\end{array}$ & damage to gills and epithelial & \\
\hline $\begin{array}{l}\text { Chlorine } \\
(\mu \mathrm{gm} / \mathrm{l})\end{array}$ & 980.8 & $\begin{array}{l}\text { Airway irritation, wheezing, } \\
\text { sore throat, cough, eye } \\
\text { irritation, skin irritation }\end{array}$ & $\begin{array}{l}\text { Necrosis in fish, damage sensitive gills and } \\
\text { the skin that covers entire body, respiratory } \\
\text { problem, red patches over body }\end{array}$ & $\begin{array}{l}\text { High } \\
\text { concentration }\end{array}$ \\
\hline $\begin{array}{l}\text { Potassium } \\
(\mu \mathrm{gm} / \mathrm{l})\end{array}$ & 0.0 & $\begin{array}{l}\text { Hyperkalemia ,hormonal } \\
\text { disorders, lupus, kidney } \\
\text { failure, uncontrolled } \\
\text { diabetes }\end{array}$ & $\begin{array}{l}\text { Mild epithelial lifting, renal edema, altered } \\
\text { renal foci ,hepatocellular vacuolation, gill } \\
\text { epithelial hyperplasia ,protozoa parasite } \\
\text { growth on gills and skin }\end{array}$ & Absent \\
\hline $\begin{array}{l}\text { Calcium } \\
(\mu \mathrm{gm} / \mathrm{l})\end{array}$ & 326.84 & $\begin{array}{l}\text { Kidney stones, high blood } \\
\text { pressure, depression, } \\
\text { nausea, vomiting, diarrhea }\end{array}$ & $\begin{array}{l}\text { Lack of calcium obstacles the growth of fish } \\
\text {,it also damage the structure of bone }\end{array}$ & $\begin{array}{l}\text { High } \\
\text { concentration }\end{array}$ \\
\hline
\end{tabular}

\section{5 (B)- transition metals}

\begin{tabular}{|l|l|l|l|l|}
\hline $\begin{array}{l}\text { Manganese } \\
(\mathrm{mg} / \mathrm{l})\end{array}$ & 2.26 & $\begin{array}{l}\text { Ataxia, fatness, blood } \\
\text { clotting, skin disorders, } \\
\text { changes in hair colour, birth } \\
\text { defects }\end{array}$ & $\begin{array}{l}\text { Dizziness and shortened breath are } \\
\text { the initial symptoms of sudden } \\
\text { metals stress, while delayed effect } \\
\text { include change in skin coloration } \\
\text { and ultimately fish death }\end{array}$ & $\begin{array}{l}\text { Trace amount of } \\
\text { manganese present }\end{array}$ \\
\hline $\begin{array}{l}\text { Iron } \\
(\mu \mathrm{gm} / \mathrm{l})\end{array}$ & 38.74 & $\begin{array}{l}\text { Joint pain, abdominal pain, } \\
\text { heart \& liver failure, hemo } \\
\text { chromatists skin damage }\end{array}$ & $\begin{array}{l}\text { Irritation of the gill tissue and gill } \\
\text { damage and secondary bacterial } \\
\text { and fungal infections }\end{array}$ & Present \\
\hline $\begin{array}{l}\text { Stannic } \\
(\mu \mathrm{gm} / \mathrm{l})\end{array}$ & 70.62 & $\begin{array}{l}\text { Irritation to eye skin and } \\
\text { respiratory system, chromo } \\
\text { somal aberrations, } \\
\text { neurological problems, } \\
\text { cancer }\end{array}$ & $\begin{array}{l}\text { Penetrate fish blood through gills } \\
\text { and intestine finding way to } \\
\text { various organs }\end{array}$ & \\
\hline
\end{tabular}

5 ( c) - Rare earth metals

\begin{tabular}{|l|l|l|l|l|}
\hline Gadolinium & 7.04 & $\begin{array}{l}\text { Nephrogenic systemic fibrosis, } \\
\text { light irritation to eye \& skin. }\end{array}$ & Necrosis and affect gills & $\begin{array}{l}\text { Trace amount of } \\
\text { gadolinium }\end{array}$ \\
\hline Europium & 0.0 & Regarded as toxic & Toxic & Absent \\
\hline Erbium & 13.52 & $\begin{array}{l}\text { No biological role erbium is } \\
\text { present in bones smaller } \\
\text { amount in liver \& Kidney }\end{array}$ & $\begin{array}{l}\text { Delay of hatching, decreased } \\
\text { standard length and heart rate as } \\
\text { well as in delayed heart formation }\end{array}$ & $\begin{array}{l}\text { Trace amount of } \\
\text { erbium }\end{array}$ \\
\hline Samarium & 5.64 & $\begin{array}{l}\text { Less biological role and it is } \\
\text { not that toxic in } \mathrm{SmCl}_{2}\end{array}$ & $\begin{array}{l}\text { Affect brachial arch }, \text { scales and } \\
\text { gills. No threat to plant and animals }\end{array}$ & $\begin{array}{l}\text { https://byjus.com/ } \\
\text { chemistry/ }\end{array}$ \\
\hline
\end{tabular}

\section{Conclusion:-}

Laterite in India special lacks geological mapping in the present Anthropocene epoch. The geo-bio- chemistry of the ponds formed within the Laterite mines in the Khordha, Puri and Nayagarh areas are studied. The laterite coverage was found by IS method to be 744.54. The pond utilization and the concerned water quality in the stagnated water bodies found unsuitable for domestic use of the stake holders of the areas. The study by different laboratory procedures and XRF spectroscopic studies it indicated abnormalities in DO level, iron and aluminium and Nickel concentration. It is anticipated that the fish kill in the ponds of laterite mines are due to aluminium and iron contamination and high DO values of the stagnated water. Search for Nitrogen toxicity, presence of prozoan parasites, study of primary nutrients, microorganisms and further regular investigation is needed to ameliorate the deficiencies of flora and fauna of the nature in the vast laterite mines area.

Acknowledgement:We are thankful to the Centurion University of technology and management who had allowed the lab. facilities and Er. Sanjeeb Ku. Pattanayk cooperated during conducting experiments. 


\section{Reference:-}

1. Buchanan (F.), 1807. - A journey from Madras through the countries of Mysore, Canara and Malabar, Vol. 2, 436-60, Rast-India Co. London.

2. Alexander L.T., Cady J.G., 1962, Genesis and hardening of laterite in soils. Tech. Bull. 1282, Soil Conservation Service, U.S. Dept. Agric.

3. Maignien R., 1966, Review of research on laterites. UNESCO, Paris.https://unesdoc.unesco.org /ark:/48223 /pf0000071101

4. Thomas, M.F. (1974): Tropical Geomorphology - A Study of Weathering and Landform Development in Warm Climate. London: MacMillan Press Ltd. PP- 49-82

5. Niyogi D., Mallick S., 1973, Quaternary laterite of West Bengal: it's geomorphology, stratigraphy and genesis. Quat J Geol Min Metal Soc India 45(4):155-174

6. Raychaudhuri, S.P. 1980: The occurrence, distribution, classification and management of laterite and lateritic soils. Journee Georges Aubet pp-249 - 252.

7. Wadia, D.N., 1999,: Geology of India. New Delhi: Tata McGraw Hill Publishing Company.

8. Ollier, C.D., Sheth, H.C., 2008, The high Deccan duricrusts of India and their significance for the 'laterite' issue. Journal of Earth System Science Vol-117 (5): pp- 537 - 551

9. Mishra S. P., Pattanaik S. Ku., Mishra S., 2018, Geo-hydro-chemistry of latosol mineralogy: SMD and western catchment of Chilika lagoon, India, Int. Jr. of Adv. Research, Vol- 6(4), pp-1133-1143, DOI: 10.21474/IJAR01/ 6962

10. Hunday, A., Banerjee, S., 1967, Geology and mineral resources of West Bengal. Calcutta:

11. Geological Survey of India, Vol-97, https://archive.org/stream/in.ernet.dli.2015.124016/

12. Mallick S, Niyogi D (1972) Some physical aspects of development of nodular laterites of West

13. Bengal. Quat J GeolMetallSoc India 44(4):155-174

14. Goswami, A. B., 1981. Hydrogeology of the lateritic terrain of Bankura and Midnapore districts, West Bengal. In: Proceedings of the Int. Seminar on Lateritisation Processes, Trivandum, India, 407-410.

15. Vaidyanadhan, R., Ghosh, R.N., 1993, Quaternary of the east coast of India, (ed) Indian Geomorphology 1. Current Science, Vol-64: pp-804-815

16. Chatterjee, N., 2008. Laterite terrains of the Chotanagpur Plateau fringe region (case study of the Mayurakshi Basin, eastern In-dia). Indian Jr. of Landscape System and Ecological Studies, Vol-31(1): pp-115-130.

17. Ghosh S., Guchhait S. Ku., 2015, Characterization and Evolution of Laterites in West Bengal: Implication on the Geology of Northwest Bengal Basin, Trans.Inst.Indian Geographers, Vol. 37 (1), pp- 1-27

18. Bandyopadhyay S (1988) Drainage Evolution in a Badland terrain at Gangani in Medinipur district, West Bengal. Geogr Rev India 50(3):10-20

19. TuncerE.1 R.,1976,Engineering behavior and classification of lateritic soils in relation to soil genesis ", Retrospective Theses and Dissertations.pp- 1-140, https://lib.dr.iastate.edu/rtd/5712

20. Mike Widdowson, (2009). Evolution of Laterite in Goa. In: Mascarenhas, Antonio and Kalavampara, Glenn eds. Natural Resources of Goa: A Geological Perspective. India: Geological Society of Goa, pp. 35-68.

21. Das K, Bandyopadhyay S., 1995, Badland development over laterite duricrust,.Int: Jog SR (ed) Indian Geomorphology 1. RawatPuplication, New Delhi, pp 31-42

22. Mishra S. P., Pattanaik S. K., 2017, Attenuating Transition Metals/REE's by X-ray fluorescent Spectroscopy of Ground Water of the South Mahanadi Delta, India, Int.l Journal of ChemTech Research, CODEN (USA): IJCRGG, Vol.10 No.15, pp 163-176, http://www.sphinxsai.com/2017 /ch_vol10_no15/2/(163-176)V10N15CT.

23. Chattopadhyay G.N., Mukherjee R., Banerjee A., 2003, Phosphorus Management for Fish Ponds Located in Red and Lateritic Soil Zones, Better Crops International,Vol. 17( 2),

24. Banerjee A., Chattopadhyay G.N., Boyd Claude E., 2009, Determination of critical limits of soil nutrients for use in optimizing fertilizer rates for fish ponds in red, lateritic soil zones, Aquacultural Engineering Vol-40(3), pp-144-148, DOI: 10.1016/j.aquaeng.2009.02.003

25. Kanwar J.S., Grewal J.S., 1991, Phosphorus fixation in indian soils: A Review, Publications and Information Division, Indian Council of Agricultural Research, KrishiAnusandhanBha van, pusa, new delid 110012

26. Oldham RD (1939) A manual of the geology of India and Burma (Revised and re-written by

27. Pascoe EH), 3rd ed. (1964 reprint). Geological Survey of India, Calcutta, pp 1344-2130

28. Niyogi, D., 1975: Quartemary Geology of the Coastal Plain in West Bengal and Orissa. Indian Journal of Earth Science 2(1): pp.51-61. 
29. Bandyopadhyay S (1987) Man-initiated gullying and slope formation in a Lateritic terrain at Santiniketan West Bengal. Geographic Review, India, Vol- 49(4), pp-21-26

30. Das K, Bandyopadhyay S (1995) Badland development over laterite duricrust. In: Jog SR (ed) Indian Geomorphology 1. RawatPuplication, New Delhi, pp 31-42

31. Das K, Bandyopadhyay S (1996) Badland development in a Lateritic Terrain: Santiniketan, West Bengal. In: Jog SR (ed) Nat Geogr 31(1 and 2):87-103

32. Dey S., Ghosh S., Debbarma C., Sarkar P., (2009) Some regional indicators of the tertiary-quaternary geodynamics in the paleocoastal part of Bengal Basin (India). RusGeolGeophys 50:884-894

33. Adnan, Amin, Taufeeq, Ahmad, Malik, Ehsanullah, Irfanullah, Muhammad, Masror, Khatak and Muhammad, Ayaz, Khan, (2010), Evaluation of industrial and city effluent quality using physicochemical and biological parameters, Electronic Journal of Environmental, Agricultural and Food Chemistry, Vol-9(5), pp 931-939.

34. Mishra S. P., Joshi A., 2017, Anthropocene Effects on the River Daya and the Lagoon Chilika by the Effluents of Bhubaneswar city India: A physico-chemical study, International Journal of Advance. Research, Vol-. 5(10),pp- 1370-1384, : http://dx.doi. org /10.21474/IJAR01/5656

35. HodaAbd El-Azim, Heileen Hsu-Kim, Chris S. E., Dario Achá, 2018, Challenges and opportunities for managing aquatic mercury pollution in altered landscapes, Ambio, 2018, Vol-47( 2);PP- 141

36. Sherman, G. D., Y. Kanehiro and Y. Matsusaka. 1953. The role of dehydration in the development of laterite. Pacific Science 7(4), 438-446.

37. McFarlane, M. J. and Bowden, D. J. (1992): Mobilization of aluminium in the weathering profiles of the African surface in Malawi. Earth Surface Processes and Landforms 17, 789-805

38. Tardy, Y., Kobilsek, B., Paquet, H., 1991. Mineralogical composition and geographical distribution of African and Brazilian periatlantic laterites: The influence of continental drift and tropical pale-

39. oclimates during the past 150 million years and implications for India and Australia. Journal of African Earth Sciences (and the Middle East), 12(1-2): 283-295.

40. Slaninova A., Machova J., Svobodova Z., 2014, Fish kill caused by aluminium and iron contamination in a natural pond used for fish rearing: a case report, VeterinarniMedicina, 59, 2014 , Vol-11: pp-573-581

41. Kale H. S., 2016, Textural and Ore Mineralogical Studies on Laterites of the Sukinda Valley of the SinghbhumCraton, Odisha (India), Ultra Scientist Vol. 28(2)B, pp-55-62 www.ultrascientist.org

42. Peuranen S, Vuorinen PJ, Vuorinen M, Hollender A, 1994: The effects of iron, humic acids and low pH on the gills and physiology of brown trout, Salmotrutta. AnnalesZoologicaFennici 31, 389-396.

43. Krishna P.V., Rao K. M., Swaruparani V., Rao D. S., 2012,Heavy metals concentration in fish Mugilcephalus from Machilipatnam coast and possible health risks to fish consumers, SDI Paper Template Version 1.6 Date 11.10.2012, http://www.sdiarticle1.org/prh/BBJ 11/2013

44. Wiebe A. H., 1933, The effects of high concentrations of dissolved oxygen on several species of pond fishes, U. S. Bureau of Fisheries Laboratory, Fairport, Iowa. Pp- 110-126, https://kb.osu. edu /bitstream/handle/1811 /2620/1 /V33N02_110.pdf

45. Lukowicz M (1976): The iron content in the water and its effect on fish (in German). Fisch und UmweltVol- 2: PP-85-92.

46. Alipore H, Paurkhabbaj A., and Hashnapour M., 2016, Determination of metals (AS, Cu, Fe and Zn), in two fish spices from the Miankaleh wet land, Arch. Pol.Fish. Vol-23: pp 99-105, DOI 10.1515/aopf- 2016, 0011, 